\title{
Bidrag til belysning af de kirkelige forhold i Vestslesvig omkring 1650.) Af Johan Hvidtfeldt.
}

\section{Ribe stift og dets omfang:}

Før 1864 hørte en stor del af Sønderjylland i kirkelig henseende under kongeriget. Fra gammel tid havde Als og AErø ligget under Fyns stift. Dette forhold ændredes først i 1819, da der oprettedes et særligt bispedømme for de to Øer. Og hele Vestslesvig fra Ribe til Vidaaen hørte oprindelig under Ribe stift. I de fleste kirkelige forhold gjaldt kongerigske love og anordninger. Dette ejendommelige forhold er urgammelt, taber sig i historiens mørke.

Helt uændret forblev forholdene dog ikke i historisk tid. Landsdelens opdeling mellem de forskellige fyrstelinier medforte uendelige stridigheder mellem biskoppen, kapitlet, kongen og de hertugelige embedsmænd. Utallige forhandlinger fortes. Og flere gange ændredes forholdene. Det endelige resultat blev' dog, at kirkerne i Tørninglen (Frøs (undtagen SkodJorg sogn), Kalvslund, Hviding og Nørre-Rangstrup herreder samt Nustrup, Gram og Skrydstrup sogne i Gram herred), der en tid efter reformationen havde været henlagt til Haderslev provsti, forblev under biskoppen i Ribe, der i 1581 fik befaling til at visitere alle kirkerne og sognene. Kirkerne i Bedsted,

*) Hvor intet andet bemærkes, findes det $\mathbf{i}$ det følgende citerede arkivstof i Landsarkivet i Aabenraa. (V.) og (Ra.) angiver, at det findes henholdsvis i Landskarkivet i Viborg og i Rigsarkivet i Køben. havn. De med Acta betegnede arkivalier er afleveret til Rigsarkivet og Landsarkivet i Aabenraa fra det preussiske Statsarkiv i Kiel. A. XX er betegnelsen for gottorperarkivet, A. XVII for den ældre del af Tyske Kancellis arkiv og A. VI for den slesvigske superindentents og biskoppen over Als og Ærøs arkiv, mens signaturen C. betegner de lokale arkiver (amtsarkiver $\mathrm{m} . \mathrm{m}$.). Ved de hyppige henvisninger til Landemodeprotokollen fra 1635-1664 og Biskop Kragelunds Kopibog, der begge opbevares i Ribe Bispearkiv i Landsarkivet i Viborg, er findestedet dog ikke angivet. Iøvrigt kan det bemærkes, at en del af Ribe Bispearkiv er afleveret fra Landsarkivet i Viborg til Landsarkivet i Aabenraa. 
Fgvad og Hellevad, hvorom det allerede 1562 siges, at de "visiteres af mester Peder (Generanus) udi Aabenraa«, blev i 1564 endelig henlagt under Slesvig stift. ${ }^{1}$ ) Ogsaa de løgumklosterske kirker Brede og Nørre-Løgum (med Løgumskloster) samt kirkerne i Tønder herred: Tønder, Ubjærg, Højer, Hjerpsted og Skast gik tabt. I 15,62 hedder det, at provsten i Tønder herred, Jorgen Petræus, havde givet meddelelse om, at han ikke turde lade biskoppen befatte sig med kirkerne i Tønder herred, før han kendte hertug Hans' vilje derom. ${ }^{2}$ ) Endnu i 1564 visiterede Kibe biskoppen Povl Madsen dog i Højer kirkè. Men nogle aar efter forbød hertug Hans præsten i Højer at svare biskoppen i Ribe »udi nogen maade paa religions vegne, men provsten af Tondern $\ll^{3}$ )

Striden om de tønderske og løgumklosterske kirker blev foreløbig afgjort ved Kolding recessen af $1576 \mathrm{og}$ hertug Augusts voldgiftskendelse af 1578. De omstridte kirker kom under hertugens overhøjhed,' og denne fik patronatsret til dem. Arkedegnen beholdt sin ret - undtagen i Nørre-Løgum - til at høre kirkeregnskaberne sammen med de fyrstelige amtsskrivere.4)

Erkedegnen var fra gammel tid regnskabsprovst for kirkerne i Hviding, Nørre-Rangstrup, Gram, Lø, Tønder og Højer herreder og kantoren - fra 1661 præsten ved St. Catharina kirke i Ribe - for kirkerne i Frøs og Kalvslund herreder. I regnskabspenge havde de en mark aarlig af hver kirke samt en nats tæring eller en mark lybsk i gæsteri af hver kirke, hvor de ikke overnattede. Senere var regnskabsafgiften to rigsdaler af hver kirke. Desuden havde ærkedegnen indfæst-

1) Kirkehistoriske Samlinger I 477 f; Kancelliets Brevbøger 1581 20/11, 1595 10/3; Kinch: Ribe Bys Historie og Beskrivelse II 482 ff.; Nye kirkehistoriske Samlinger VI 519 ff.; Tyske Kancelli: I. A. 1670. X. "Die geistliche Jurisdiction des Bischofs zu Ripen betreffend « (1483-1668) (Ra.).

2) Ty. Kanc. - 1670: "Die geistliche Jurisdiction.... (Ra.); jvnfr. Andresen: Geschichte der Stadt Tondern 163 ff. og Sønderjyllands Historie II 354 f. $25 \mathrm{ff}$.

3) Claus Rolfs: Geschichte des Kirchspiels und Fleckens Høyer

4) Staatsbürgerliches Magazin V. 461 ff., 465. 
ningen af kirketiender og kirkejorder i Lø herred og Møgeltonder birk (undtagen Ballum). ${ }^{5}$ )

Til bestridelse af de almindelige provstepligter, var der herredsprovster, som paa grund af herredernes eller birkernes ringe omfang $i$ flere tilfælde havde flere herreder eller birker under sig. ${ }^{6}$ )

Erkedegnen beholdt altsaa efter 1578 sin ret til - omend sammen med de fyrstelige amtsforvaltere - at høre kirkeregnskaberne i disse sogne (dog ikke i Nørre-Løgum). Regnskaberne er derfor underskrevet af begge disse mænd.7) Samvar ikke altid det bedste. Kompetencestridigheder hørte til dageus orden. I 1649 klagede hele kapitlet til kongen over de fyrstelige embedsmænd. Amtsskriveren i Logumkloster havde faret indbydelse til at forhøre regnskabet den 20. november. Nen han havde undskyldt sig og var kommet med udflugter. Han kunde ikke give møde, ".... dermed kapitlet deres højhed og rettighed at ville betage og forvilde.... Heller. ikke amtsskriveren i Tønder vilde komme til den fastslaaede tid. $\mathrm{Og}$ borgmester og raad i Tønder, der - som det hævdes - uden hjemmel deltog i overhøringen af Tønder kirkes regnskab, havde hørt regnskabet alene. ${ }^{8}$ ) Striden om Tønder kirkes regnskab fortsattes $\mathrm{i}$ den følgende tid. 1655 beklagede biskop Kragelund, der fra 1652 ogsaa beklædte ærkedegneembedet, sig over det samme. Det var efter hans mening, "... at gribe Kong Majestæt ind udi hans højhed eftersom kirken i Tønder

5) Kinch: anf. ster II 510, 515; Ty. Kanc. - 1670: "Die geistliche Jurisdiction.... (Ra.); Topografica: Haderslev Amt: (1434-1748) "Copiale von Privilegien und Verordnungen p. p. betreffend Stadt und Amt Hadersleben« 321.

$)$ Se fortegnelsen over de enkelte provster hos Arends: Gejstligheded i Slesvig og Holsten III $98 \mathrm{ff}$.

7) Se for eksempel Skast kirkeregnskabsbog, hvor ærkedegnen underskriver til 1656. Regnskaberne for 1657-1660 mangler, men 1661 er det i stedet for ærkedegnen provsten i Tønder, der har hørt regnskabet; jvnfr. ogsaa Broder Boysens bemærkning 1609 (Jahrbücher für die Landeskunde $V$ 205) og Løgumkloster amts jordebog 1607 (Acta A.'XX 2185 i Ra.).

arbejdet mellem den fyrstelige og den kongelige embedsmand

s) Ty. Kanc. - 1670: "Die geistl. Jurisdiction...." (Ra.). 
hører til Riber kapitel og Danmarks krone.... . Det tilkom orkedegnen paa kongens vegne at fastslaa det tidspunkt, paa hvilket regnskabet skulde afhøres. $\left.{ }^{\circ}\right)$

Aaret efter opnaaedes der dog en ordning med hensyn til uoverensstemmelserne med amtsskriveren i Tønder, idet kongen henstillede til hertugen af Gottorp, at man, ligesom det var sket i Haderslev amt, skulde fastsætte en bestemt dag om foraaret, hvorpaa regnskabet kunde afhøres. Hertugen anbefalede derefter sin amtsskriver at enes med biskoppen om en dag i marts. ${ }^{8}$ )

At hertugen af Gottorp i 1658 fik suverænitet over sit omraade, fik hurtigt betydning for spørgsmaalet om ærkedegnens rettigheder overfor de gottorpske kirker. Tønder bys borgmester og raad spurgte paa Gottorp, hvorledes de skulde forholde sig overfor ærkedegnen, der havde meddelt, at han snart vilde komme paa regnskabsvisitats. De mente ikke, at han efter den nye traktat havde nogen ret dertil. Et fyrsteligt brev af 20 . maj 1661 gav dem fuldstændigt medhold i dette synspunkt, ligesom det ogsaa heri udtaltes, at det ikke kunde tillades biskoppen at visitere kirkerne $i$ landsognene. ${ }^{10}$ ) En længere strid fulgte. Amtsskriveren i Tønder meddelte i 1662 biskoppen, at han havde faaet en resolution fra Gottorp, der gik ud paa, at biskoppen ikke længere maatte præsidere eller »die Direction führen" ved afhøringen af kirkeregnskaberne. Dog kunde han faa lov at overvære regnskabsaflæggelsen, da der fandtes kongelige undersaatter i sognene. Biskoppen henvendte sig til oversekretæren i Danske Kancelli Erik Kragh og gjorcle rede for sagen. Ogsaa ved forskellige andre henvendelser søgte han at faa spørgsmaalet taget op til drøftelse og undersøgelse, saaledes ved et brev til feltherren Hans Schack. ${ }^{11}$ ) Der synes ikke

9) Biskop Kragelunds Kopibog 74.

8) Ty. Kanc. - 1670: "Die geistl. Jurisdiction...." (Ra.).

10) C. F. Allen: Det danske Sprogs Historie i Hertugdømmet Slesvig eller Sønderjylland I $71 \mathrm{f}$.

11) Biskop Kragelunds Kopibog 144, 163 f, 196; Ty. Kanc. - 1670: „Die geistl. Jurisdiction.... (Ra.). 
at være kommet noget ud af disse henvendelser. Først en del aar senere - vistnok i 1668 - udnævnte kongen og hertugen kommissærer til at fælde kendelse i dette stridsspørgsmaal. Den kongelige "Anwalt«, licentiat Otto Mauritius, og den fyrstelige repræsentant Hartwigh Blüting indsendte begge skrifter til kommissærerne, hvori der redegjordes for det kongelige og det hertugelige standpunkt i sagen. Egentligt nye synspunkter kom der ikke frem. Det springende Punkt var fortolkningen af suverænitetsbestemmelsen i recessen af 2 . maj 1658, hvori det blandt andet lied, at rigsgrænserne skulde forblive "... in ihren uhralten limitibus undt scheiden auff allen Seiten unverendert, undt das Reich in seinem Bezirk bey dero geistlichen undt weltlichen jurisdiction $\mathrm{zu}$ lande undt Wasser unperturberet nach wie vor gelassen werden .... «. Ligesaalidt som andre steder i recessen var der her direkte tale om ærkedegnens rettigheder med hensyn til de tønderske og løgumklosterske kirker. Der var derfor forholdsvis frit raaderum for juristernes fortolkninger. Selv om det maa indrømmes, at udtrykkene ikke er præcise og klare, synes det dog nærliggende at udlægge recessens bestemmelser om, at den gejstlige jurisdiktion skulde forblive "unperturberet«, saaledes, at meningen var, at ærkedegnens ret ikke kunde antastes. ${ }^{12}$ )

Men resultatet blev i hvert fald det modsatte. Det var herefter provsten i Tønder, der hørte de tønderske og løgumklosterske kirkers regnskaber sammen med amtsskriverne. Kun under sekvestrationen fra 1684-1689 var de tønderske kirker og Brede kirke atter henlagt under Ribe biskoppen. ${ }^{13}$ )

Selvom Haderslev amt ved delingen efter hertug Hans den ældres død blev kongelig, var der dog ogsaa her store vanskeligheder med hensyn til afhøringen af kirkeregnskaberne. Amtmanden i Haderslev søgte paa alle tænkelige maader at

12) Ty. Kanc. - 1670: „Die geistl. Jurisdiction ...» (Ra.); Danmarks Traktater V 290; jvnf. Allen: anf. sted 72.

18) Ribe Bispearkiv: Archidiakonatets Dokumenter vedr. Tørninglen 1576-1778; Rolfs: Geschichte des Kirchspiels und Fleckens Hoyer $31 \mathrm{ff}$; Allen: anf. sted 73. 
tilrive sig saa stor ndflydelse og saa mange rettigheder som mulig. Og her kunde biskoppen ikke pukke paa, at Kongelig Majestæts ret blev krænket. Begge var kongelige embedsmænd.

Ligesom i Tønder amt drejede stridighederne sig ogsaa her om, hvem der skulde fastsætte tiden og stedet for afhøringen af regnskaberne. I 1587 befalede amtmanden paa kongens vegne, at ærkedegnen den 27. november skulde komme til Haderslev, hvor amtmanden vilde beordre alle fogder og kirkeværger til at give møde. Sen'ere klarede man dette spørgsmaal ved at fastsætte en bestemt dag for afhøringen af regnskaberne.

En stor strid først i 1590erne mellem amtmand Hans Blome og ærkedegnen Erasmus Heitmann var maaske snarere af personlig art. Der rejstes stærke anklager mod ærkedegnen for at være gaaet ganske egenmægtigt frem ved afhøringen af regnskaberne. Han foretog denne alene og vilde ikke tilstede, at nogen præstemand, kirkeværge eller sognemand var hos ham og hørte regnskabet. Han afgjorde alting alene og $\mathrm{i}$ løndom hjemme $i$ sit herberge. Ingen vidste, hvad han gjorde med pengene, om han satte dem paa rente eller ej. Engang havde en mand i Rangstrup bebrejdet ham, at regnskabsaflæggelsen ikke var saa aaberibar og offentlig, som tilfældet før havde været. Mester Erasmus havde da i mange af Agerskov sognefolks paahør givet ham sonde ord «. Arkedegnen benægtede de fremførte paastande. Han havde ligesom tidligere afhørt kirkeregnskaberne i kirkerne i præsternes, kirkeværgernes og sognefolkenes nærværelse. ${ }^{14}$ )

Mester Erasmus var iøvrigt en mand, der ikke altid kunde enes med de mennesker, han skulde arbejde sammen med. 1586 havde han, for eksempel en større strid med Benedict Rantzau til Møgeltønder. Der blev i den anledning udnævnt tre kommissærer, der skulde afhøre de vidner, ærkedegnen vilde føre. Ogsaa her drejede det sig om kirkeregnskaber og bortfæstelse (af kirkejord. ${ }^{15}$ )

14) Ty. Kanc. - 1670: "Die geistl. Jurisdiction.... (Ra.).

15) Kancelliets Brevbøger 1586 16/6. 
Et andet stridsspørgsmaal var afhøringen af Vester-Vedsted og Brøns kirkers regnskab. I henhold til Kolding afskeden mente man i Ribe, at amtmanden i Haderslev ikke havde noget at gøre dermed; men alligevel gav amtsskriveren ogsaa her møde, ligesom han tog fjerdedelen af sognetienderne og indfæstningen af kirkejorderne med sig til Haderslev ${ }^{16}$ )

Det kan i denne forbindelse nævnes, at der - i hvert fald fra 1642 - var indsat særlige kirkeskrivere. Jesper Hansen i Langetved, hvis bestalling udstedtes af amtmanden den 14. oktober 1642, skulde i Nørre Rangstrup, Gram og Hviding herreder »....skrive og antegne kirkernes aarlige indtægt og udgift, naar kirkens regnskab af provsten bliver forhørt, og derhos tage vel $\mathrm{i}$ agt kirkens rettighed og højhed, som hører til Haderslevhus.... H. Hans efterfølger var ridefogden i Hviding og Nørre Rangstrup herreder Hans Outzen, der boede i Brøns, og derefter fra 5 . november 1681, var dette kirkeskriverembede altid forbundet med herredsfogedembedet for Hviding og Nørre Rangstrup herreder. ${ }^{17}$ )

\section{Præsternes afstamning og studier: $^{18}$ )}

I den tid, der her er tale om, var befolkningen og præsterne sikkert meget nøjere knyttet til hinanden end nu, og de unge præstesønner, der drog til landets hovedstad eller til fremmede lande for at studere og uddanne sig til en præstegerning, vendte i mange tilfælde tilbage til deres fødesogn som faderens efterfølger. Eller de søgte og fik kald i den landsdel, som i snævreste forstand var deres hjemstavn. Dette forhold slaar en, naar

$\left.{ }^{16}\right)$ Ribe Bispearkiv: Frkedegnen Ægidius Laurentius' Regnskabsbog for Kirkerne i Lø Herred m. v. 1613-1620 (V.); Ty. Kanc. - 1670: "Die geistl. Jurisdiction...." (Ra.).

17) Acta A. XVII 802 (Ra.); Topografica. Haderslev Amt: (14341748) "Copiale von Privilegien und Verordnungen p. p. betr. Stadt und Amt Hadersleben « 318. Stiftsskriverne indfortes allerede i 1631, og aaret efter udnævntes en saadan for Ribe stift (Kancelliets Brevbøger 1631 28/7, 1632 13/2). Om Jesper Hansen se Barfod: Borgerlige Rigsdagsmænd 1660.248 ff.

${ }_{18}$ ) Det følgende afsnit er udarbejdet paa grundlag af oplysningerne i Arends anførte værk. 
man betragter de præster, som i tiden fra 1635 til 1664 har virket $i$ de dele af Sønderjylland, som hørte til Ribe stift (heri ogsaa indbefattet de sogne, som i 1864 forblev ved Danmark). For ca. femtens vedkommende savnes enhver oplysning om deres fødested. Af de øvrige 57 var

23 født i Vestslesvig

5 født i det øvrige Nordslesvig

1 født i Flensborg

28 født i Danmark (heraf en paa Færøerne):

Som man ser, var ikke een eneste født i Holsten eller i Tyskland. Af dem, der var født i Vestslesvig, blev ikke mindre end 13 præster i deres fødesogn. De 28 præster fra Danmark var næsten alle fra Ribe, hvilket ikke blot hænger sammen med denne bys ret betydelige størrelse endnu paa denne tid, men sikkert ogsaa i høj grad skyldes det forholdsvise store antal af gejstlige, der var i byen. De fleste praster kom jo fra præstehjem.

Med hensyn til præsterne i de vestslesvigske sogne, der paa denne tid hørte til Slesvig stift (Nørre-Løgum, Brede, Tønder, Ubjærg, Abild, Højer, Hjerpsted og Skast), var forholdet lidt anderledes. Af de 12 præster fra tiden 1635-1664, om hvis fodested, der haves oplysninger, var
5 født i Vestslesvig
2 født i det øvrige Nordslesvig
5 født $i$ det øvrige Slesvig. $\left.{ }^{19}\right)$

Langt de fleste af de unge mænd, som senere skulde blive præster i Vestslesvig, fik deres første akademiske uddannelse ved latinskolen i Ribe. ${ }^{20}$ ) Men hvor drog de saa hen derfra? Gik rejsen kun til landets universitet, til hovedstaden, eller følte de som vel alle tiders og alle landes ungdom gør og har gjort - trangen brænde i sig til at lære nye og større forhold

19)) Enkelte af disse fem er dog lidt usikre.

$\left.{ }^{20}\right)$ Angaaende sønderjyske dimittender fra Ribe Katedralskole se: Personalhistorisk Tidsskrift 1936. $97 \mathrm{ff}$. 
i fremmede lande at kende? Perioden er jo den adelige ungdoms store rejsetid. Præstesønnerne var ikke saa godt aflagt, men afsted kom mange af dem alligevel. I 45 tilfælde vides det med nogenlunde sikkerhed, hvilke universiteter de senere præster i det daværende Ribe stift har frekventeret. 27 har kun været i København, een, om hvem oplysningeme iøvrigt ikke er helt sikre, har kun været paa universitetet i Rostock, mens 17 har været baade i København og i udlandet. I hvilken or. den man tog de forskellige universiteter, var iøvrigt meget forskellig. At alle de studerende saa at sige uden undtagelse har studeret $i$ København undrer ikke. Der var vel ikke som $i$ aldre tid noget paabud om, at studenterne forst skulde have besøgt univer'sitetet $i$ København, inden de drog udenlands. ${ }^{21}$ ) Men enhver, der ønskede kald $i$ en af de kongerigske kirker, var faktisk tvunget til i nogen tid at have studeret $i$ København, thi den store kirkelige forordning af 27. marts 1629 indskærpede, at ingen maatte optræde paa prædikestolen, med mindre han havde været paa universitetet i København eller havde testimonium derfra. ${ }^{22}$ ) Iøvrigt blev der ydet studenterne fra Haderslev amt støtte til deres udenlandske studier, idet hver kirke i amtet, ogsaa de tørninglenske, fra gammel tid maatte betale en rigsdaler $i$ sstudenterpenge" til legater for saadanne studerende. Pengene opkrævedes af kirkeskriveren ved regnskabsaflæggelsen og afleveredes til provsten i Haderslev. Antagelig er disse penge ogsaa blevet ydet til folk, der studerede i København. ${ }^{23}$ )

Langt de fleste af dem, der drog ud, tog - som det var at vente - til Tyskland. Det laa jo nærmest. Og af de tyske universiteter var Rostock det absolut dominerende. Ialt 12 af de senere præster i Ribe stift rejste derned. Heraf besøgte dog

21) Slesvigske Provindsialefterretninger Ny Række III 5.

22) H. F. Rørdam: Danske Kirkelove III 158 ff, 175.

23.) Kirkehist. Samlinger I 479; Slesvigske Provindsialefterretninger Ny Række III 7; Top. Haderslev Amt: (1434-1748) "Copiale von Priv. u. Verordn. p. p..... 323. At afgiften ogsaa betaltes af de tørninglenske kirker, fremgaar af kirkeregnskabsbøgerne og af Jyske Tegnelser XIII 316 f. (Ra.). 
halvdelen ogsaa andre universiteter i Tyskland. Efter Rostock var Wittenberg den mest eftertragtede lærdomsanstalt, ialt fire havde været der. Jena besøgtes af tre, Leipzig, Leiden og Strasbourg hver af to og Greifswald, Königsberg, Danzig, Basel og Orleans hver af een.

Med hensyn til præsterne i de vestslesvigske sogne, der hørte under Slesvig stift, var forholdet et andet. Af de 12 præster, om hvis studier der haves oplysning, havde kun een studeret $i$ København, og han var fra Ballum, altsaa fra et kongerigsk sogn. Af de øvrige havde een studeret baade i København og i udlandet. De øvrige 10 havde udelukkende studeret ved tyske universiteter, først og fremmest Rostock. Forholdet er ikke enestaaende. Det var paa denne tid ikke særlig almindeligt, at præster under Slesvig stift søgte til universitetet i København. De fleste gik til de tyske universiteter. ${ }^{24}$ )

\section{Præsternes kaldelse:}

Naar studierne var afsluttet, og den unge mand havde samlet lærdom og erfaring, skulde han have kald. Hvordan blev man paa denne tid kaldet til præst $\mathrm{i}$ disse sønderjyske sogne? Fremgangsmaaden ved de nye præsters udvælgelse var for Danmarks vedkommende fastslaaet i kirkeordinansen af 1539 og senere stadfæstet og nærmere udformet. Syv mænd, kaaret af sognet, skulde sammen med provsten udvælge den, de mente skikket til at blive deres sognepræst. Derefter skulde biskoppen overhøre ham og lensmanden anerkende valget. Først da kunde han blive ordineret. ${ }^{25}$ )

Fremgangsmaaden ved præstevalget var omstændelig, og forholdet blev ikke bedre ved, at saa mange forskellige autori-

24) Angaaende de slevigske studenters studier, især ved Københavns universitet, se Th. O. Achelis i Archiv für Kulturgeschichte XVIII 287 ff.

${ }^{25}$ ) Ved forordningen af 20/5 1670 bortfaldt amtmandens anerkendelse af valget. Et brev af 18/1 1732 indskærpede, at dette ogsaa gjaldt for Tørninglen (Top. Haderslev Amt: (1434-1748) "Copiale von Priv. u. Verordn. p. p..... 564 ff.). 
teter havde med sagen at gøre. Og naar der saa som i Tørninglen var tale om myndigheder, hvoraf de to, biskoppen $\circ g$ provsten, var kongerigske og sorterede under Danske Kancelli, mens den tredie, amtmanden i Haderslev, hørte under hertugdømmet og sorterede under Tyske Kancelli, forstaar man, at der let kunde komme rivninger. Og det kom der. Striden kom især til at dreje sig om den rette fortolkning af brevet af 1581 angaaende Tørninglens forhold til Biskoppen. Det hed deri, at denne "... skulde visitere alle de kirker og sogne udi Sønderjylland udi Tørning len.... og til dennem at skulle have den indseende, som en kristelig superintendent og biskop bor at have.... Han skulde have indseende med, "... at Guds ord sammesteds prædikes purt og rent, uforfalsket, og at med alting udi religionen og kirketjenesten kristeligen forholdes og handles efter den gejstlige ordinans, som om religionen her udi riget er udgangen.... $\ll^{2{ }^{2} \mathrm{f}}$

De haderslevske amtmænd, der i aarhundredet 1585-1684 alle tilhørte de store holstenske adelsslægter Blome, Rantzau, Buchwald, Ahlefeldt og Reventlow, betragtede problemerne udfra deres egne synspunkter, der var betinget af forholdene i hertugdømmerne og de særlige retsregler, der gjaldt her. En vis betydning for deres opfattelse har Kolding recessen ogsaa haft. Flere gange paaberaabes den under stridighederne. Amtmændene hævdede, at brevet af 1581 nok gav biskoppen ret til at visitere kirkerne, men overhøjheden, jus patronatus og jus episcopale, hørte til amtet. Biskoppens opfattelse var derimod, at de danske lovregler med hensyn ti], præstevalg ogsaa skulde være gældende i Tørninglen i henhold til brevet af 1581. Det afgørende maatte dog selvfølgelig blive, hvilken stilling regeringen tog til spørgsmaalet. Der kan ingen tvivl være om, at det i 1581 var dens mening, at paa dette som paa andre omraader skulde danske regler gælde i Tørninglen. Og denne opfat' telse blev ogsaa knæsat flere gange i den følgende tid. Den 1.

${ }^{26)}$ H. F. Rørdam: Danske Kirkelove II 332. 
Oktober 1629 indskærpede et kongeligt brev (fornyet 26. marts 1653) gejstligheden $i$ den del af Haderslevhus len, der hørte under Ribe stift, "....at I aldeles og uden nogen exception in rebus ecclesiasticis rette eder efter ordinansen og andre kongelige forordninger, som allerede udgangen er eller her efter udgaar...... Vigtigere var det dog, at et brev af samme dato til biskoppen i Ribe udtrykkelig fastslog, »....at med præstekald, naar noget ledigt bliver, skal forholdes efter ordinansen og andre kongelige forordninger. ... $\left.{ }^{27}{ }^{27}\right)$

Regeringens stilling var i disse tilfælde klar og tydelig, og talrige eksempler viser ogisaa, at reglen var, at præsterne blev valgt efter de danske love. Men efterhaanden lykkedes det amtmanden i Haderslev i mange tilfælde at tvinge sin opfattelse igennem paa trods af lov og ret og uden hensyn til menigheden. Helt kan regeringen dog ikke siges at være fri for medansvar $\mathrm{i}$ denne udvikling. Trods sin principielt klare indstilling kunde den $i$ sine afgørelser i de enkelte tilfælde ofte være uklar og $\mathbf{i}$ modsætning til de synspunkter, den ellers almindeligvis hævdede. Forklaringen herpaa er utvivlsomt, at baade Danske Kancelli og Tyske Kancelli kunde behandle spørgsmaalet og tage stilling dertil, begge ud fra deres særlige indstilling og deres forskellige synspunkter. I det følgende redegøres for en del embedsbesættelser, som dels viser amtmandens og biskoppens stilling i de enkelte konkrete tilfælde, dels belyser regeringens mangel paa konsekvens i sin holdning overfor dette spørgsmaal. ${ }^{28}$ )

Hans Blome, der var amtmand fra 1585 til 1593, var en dygtig embedsmand, der havde spillet en fremtrædende rolle indenfor den gottorpske forvaltning. Men sin myndighed holdt han stærkt paa. I 1589 havde den gamle Hr. Niels Wulff' i Bev-

$\left.{ }^{27}\right)$ H. F. Rørdam: Danske Kirkelove III 171; Top. Haderslev Amt: (1434-1748) "Copiale von Priv. u. Verordn. p. p.... 58 f., 71 f., 99, 101 f. $208 \mathrm{f}$. og $297 \mathrm{ff}$; Kancelliets Brevbøger $16291 / 10$; jvnfr. brevet af $168423 / 7$, hvor det samme indskærpes.

$\left.{ }^{28}\right)$ Foruden de følgende tilfælde se Sønderjyllands Historie II 354 f, og 495 samt der anført litteratur; Top. Haderslev Amt: (1434-1748) "Copiale von Priv. und Verordn. p. p....« 318 ff., 284 f og 482 ff. 
toft-Tislund indsat $\sin$ søn $i$ Tislund embedet uden at spørge ham - som om det var hans arv eller ejendom. Hans Blome bad biskoppen om ikke for fremtiden at eksaminere eller indsætte nogen præst uden tilladelse fra øvrigheden paa Haderslevhus. "... jus patronatus, højhed og rettighed hører her aldeles til Haderslevhus til at lade præsterne kalde, ind- eller afsætte dem efter sagens belejlighed og vilkaar....«. Hr. Niels' søn maatte se at skaffe sig et andet embede. ${ }^{20}$ )

En anden gang Hans Blome søgte at gøre sin indflydelse gældende, var, da han præsenterede David Jespersen Brun, søn af herredsprovsten i Stepping Jesper Brun, til præst i Farup. Han havde tre gange ladet sig høre i kirken, og sognemændene havde erklæret sig tilfreds med ham. Han sendtes derefter til bispen med anmodning til denne om at eksaminere og ordinere ham. Anmodningen ledsagedes af følgende betragtning: "... at jus patronatus af den kirke aleneste til slottet hører, og eder eller eders lige tilkommer at visitere, eksaminere og ordinere .... . Han vilde ikke forkrænke nogens rettighed, men hvad han har forefundet og »annammet«, det vil han forsvare. ${ }^{29}$ ) Amtmandens udtalelser var en udfordring, og biskoppen maa have taget handsken op. Lensmanden i Ribe, Albert Friis, indberettede sagen til regeringsraadet. Den 13. januar 1592 meddelte dette, at dronningen havde faaet underretning om sagen, og at hun vilde sørge for, "at det igen skal blive afskaffet«i Endnu i december er sagen ikke afgjort, idet Albert Friis da faar paabud om, at lade sagen være $i$ bero, indtil han faar nærmere besked. ${ }^{30}$ ) David Brun blev ikke præst i Farup, hverken denne gang eller senere.

Ogsaa de følgende amtmænd hævdede, at de havde ret til at præsentere præsteemnerne for menigheden. Saaledes blev Peter Petersen Wulff, der i 1646 skulde være subsitut i Arrild, præsenteret af amtmanden. I begyndelsen gjorde sognemæn-

29) Ribe Bispearkiv: Indkomne Breve 1569-1685 (V.).

${ }^{29}$ Rabe Bispearkiv: Indkomne Breve 1569-1685 (V.).

30) Kancelliets Brevbøger 1592 13/1, 15/12. 
dene vrøvl, men tilsidst gik de dog med til at give ham kaldsbrev. Selvom kongen meddelte biskoppen, at han $i$ henhold dertil maatte indsættes, blev han dog ikke præst i Arrild. ${ }^{31}$ )

I den følgende tid stod stridighederne om de tørninglenske præstekald mere end nogensinde før paa dagsordenen. Baade i Ribe og i Haderslev sad der mænd af betydelig dygtighed og viljekraft: amtmand Cai Ahlefeldt og biskop Peder Kragelund. Den sidste var en nidkær gejstlig, der stærkt gik ind for bevarelsen af de rettigheder, der tilkom ham som biskop og arkedegn. Hans arbejde for at bevare retten til at afhøre de tonderske kirkeregnskaber er tidligere omtalt. Ogsaa i forholdet til amtmanden i Haderslev tog han et stærkt og bestemt standpunkt.

Den 6. april 1653 befalede han præsterne i Lintrup og Rejsby at sørge for, at Peder Jordt holdt sig fra al gudstjeneste i Nustrup kirke, indtil han havde faaet speciel kongelig befaling dertil, eller det ulovlige kaldsbrev, han havde faaet. var blevet. legitimeret ved lovlig proces. Brevet var kun underskrevet af een sognemand, og amtmanden havde givet provsten ordre til at beføje sig til Nustrup og høre kandidatens prædiken'»... og mig derud $i$ aldeles forbigaaet, thi præpositus at commendere in causes ecclesiasticis formener jeg superintendenten udi Ribe og ej lensmanden alene at tilkomme .... «. Peder Jordt vilde ikke møde for biskoppen, og han havde hverken testimonium fra København eller noget andet universitet. Biskoppen erklærer overfor amtmanden, i Haderslev, at det ikke i loven er ham muligt at finde noget om den præsentation, amtmanden foregiver at have ret til, "... og kan falde disputerligt, hvorledes. det jus præsentandi skulde forstaas, indtil Hans Kgl. Majestæt det selv forklarer ...... Amtmandens konfirmationsret betvivler han derimod ikke. Biskoppen tabte iøvrigt i denne strid, forsaavidt som Peder Jordt blev sognepræst i Nustrup..$^{32}$ )

s1) Ribe Bispearkiv: Reskripter 1637-1666 (V.).

${ }^{32}$ ) Kragelunds Kopibog $16 \mathrm{ff} ; 22$. 
I et brev til kancellisekretæren om denne sag beklagede biskoppen sig iøvrigt over, at naar et kald blev ledigt, begav ansøgerne sig straks til amtmanden, som sagde, at han havde jus præsentandi, i stedet for at de, som de burde, henvendte, sig til provsten. Undertiden holdt de prøveprædikener og fik kaldsbrev, uden at provsten fik noget at vide derom. Resultatet af klagen blev et kongebrev, der indskærpede bestemmelserne $\mathrm{i}$ brevet af 1 . oktober $1629 .^{33}$ )

En anden præstebesættelse, som voldte stor strid, var i $\mathrm{Hy}$ gum. 1654. Der var præsenteret tre Kandidater. 63 af sognemændene valgte Peter Jacobsen, de 7 udnævnte og enkelte andre en anden: Petrus Severini. Provsten var meget utilfreds med valget og hævdede, at da sognefolkene kom til det, havde de lige været til en begravelse, hvor de havde faaet for meget at drikke, og de havde givet ham mange unyttige ord, indenfor og udenfor kirken. Havde han vidst, at de havde lavet saadan en tumult, vilde han hellere have resigneret end være provst for dem. Hele valget gik imidlertid om. Kongen bestemte, at nye kaldsmænd skulde udnævnes, og at den ældste herredspræst skulde være tilstede i stedet for provsten. Den, der valgtes, skulde have kaldet, "... und ist hier bey nicht anzusehen, dass der eine presentatus kein attestatum und dimission von der universitet Copenhagen hat, weile solches in unseren fürstemthumber auch an fürstl. Gottorfischer Seite nicht attendiret wird.... . Det var et underligt standpunkt, regeringen her indtog. Det var direkte imod det kongelige brev fra det foregaaende aar, der netop havde indskærpet, at de torninglenske præster skulde rette sig efter ordinansen og de kgl. forordninger, der udtrykkelig forlangte testamoniet. En anden sag var det, at denne afgørelse kunde blive et farligt præcedens, der let kunde svække den kongerigske indflydelse i disse egne, blive indledningen til; at de vestslesvigske sogne gled bort fra Ribe stift, hvad der $i$ tidens løb vilde have kunnet fore til en svækkelse af danskhedens stilling $i$ disse egne. Det er selvfølgeligt et synspunkt,

33) Kinch: Ribe Bys Historie II $485 \mathrm{f}$. 
betinget af nutidens nationale opfattelse, som ikke eksisterede for datidens mennesker.

Valget gik, som man kunde have ventet. Peter Jacobsen, der netop var kandidaten uden testimonium, blev valgt. Biskoppen eksaminerede ham derefter. Han var ikke saa vel befaren i sin lærdom, men da Biskoppen mærkede, at det var kongens ønske, at han skulde have kaldet, lod han det passere. ${ }^{34}$ )

Nogle aar efter var det galt med en anden studiosus, Henning Fischer, som amtmanden agtede at præsentere til kaldet i Skærbæk, uagtet han ikke havde testimonium. Han hævdede overfor biskoppen, at sligt ikke paa de steder blev saa præcist observeret, naar de paagældende iøvrigt havde studeret andre steder og var kvalificeret. Men biskoppen mente noget andet. Der maatte handles efter de kongelige forordnịger. Tidligere undtagelser havde kun været i henhold til særlige dispensationer eller $i$ nødstilfælde ${ }^{35}$ ) Ogsaa her trak biskoppen det korte straa. Henning Fischer blev medhjælper hos Søren Pedersen Hegelund i Skærbæk.

Den voldsomste strid, der i dette tidspunkt udkæmpedes om valgretten, gjaldt delvis spørgsmaalet om lensmandens ret til at præsentere. Det var i $165 \%$, da Bevtoft-Tislund skulde besættes. Der var to Kandidater: Niels Rasmussen, hører i Ribe, og Jørgen Boysen. Det begyndte med, at ridefogden Hans Outzen paa leusmandens vegne udstedte en skriftlig præsentationsseddel til herredsprovsten, gaaende ud paa, at denne skulde præsentere Niels Rasmussen. Nogen tid derefter udstedte provsten og syv mand i henhold til præsentationsbrevet et kaldsbrev for $N$. R. Men nogle uger $\mathrm{i}$ forvejen havde andre syv mænd udstedt kaldsbrev for Jørgen Boysen. Sagen behandledes flere gange for landemodet, saaledes den 16/11, 30/11 og sidste gang den

${ }^{34}$ ) Acta A. XVII. 804 (Ra.); Kragelunds Kopibog 55 f., 58 f. Det kan iøvrigt bemærkes, at Peder Jacobsen havde studeret baade $i$ Rostock og i København (Arends: anf. værk I 373).

$\left.{ }^{35}\right)$ Kragelunds Kopibog $137 \mathrm{f}$. 
2/12. To dage senere blev den afsluttet ved forlig mellem de to parter. Jørgen Boysen fik kaldet. ${ }^{38}$ )

Iøvrigt synes det efter 1660 at være blevet ganske almindeligt, at amtmanden i Haderslev præsenterede kandidaterne, undertiden kun een, undertiden flere. I 1668 meddelte han saaledes biskoppen, at han "den Herkommen nach" havde præsenteret Hr. Johannes Stuere til præst i Skr̈ydstrup. ${ }^{37}$ ) Undertiden ser man dog ogsaa kongen gribe direkte ind. Den 21. maj 1670 befalede han saaledes amtmanden at præsentere student Petrus hylling til det ledige embede i Højrup og meddele biskoppen det. Nogle uger efter blev Clemens Povlsen Bruun dog tilskikket og forordnet til dette kald, og den 25. august gaves der ordre til at indsende brevet af 21 maj til kancelliet. ${ }^{38}$ )

I senere tid var forholdet det, at provst og amtmand præsenterede tre personer. Menigheden valgte en deraf, og valget konfirmeredes derefter af kongen. ${ }^{39}$ )

Efter at selve valget var $i$ orden, fandt den højtidelige indførelse i embedet sted. I 1698 beskrev kirkeskriveren i Hviding og Nørre Rangstrup herreder denne højtidelighed saaledes: „... Wann aber die Introduction geschiehet, alsdann ist kegenwertig des Hrr. Ambtmanns von Hadersleben dazu verordneter Gevollmächtigter und der Hardes Propst in selbigen Harde. Nach geendigter Predigt, welche von dem neuen Prediger gehalten wirdt, thut zuerst des Hrr. Ambtmanns Gevollmächtigter im Nahmen seines hohen Principalen eine Rede an der Gemeine, nimbt darauf Ihro Königl. Mayestät allergn. Confirmation und verlieset selbe laut und offenbahr, und wann derselbe geschlossen, machet der Hardes Probst gleichfalls eine Rede an der Gemeine und lieset darauf des Hrr. Bischoffs an Ihm ergangenes Schreiben, womit dann der Introductions actus

$\left.{ }^{36}\right)$ Ang. enkeltheder i sagen se Sønderjydske Aerbøger 1927. 157 -60. Landemodeprotokollen 150 ff.; Kragelunds Kopibog 83 ff.

37) Ribe Bispearkiv: Archidiakonatets Dokumenter vedr. Tørninglen $1576-1778$.

38) Acta A. XVII. 802 (Ra.). Peter Kylling blev aldrig præst, men en meget kendt botaniker (se Biografisk Leksikon XIII 477 f.).

${ }^{39}$ ) Aagaard: Beskrivelse over Tørning Lehn 130. 
zu Ende. Dem Hrr. Superintendenten wird weder wegen der Ordination, noch dem Hardes Probsten vor die Introduction was bezahlet oder gegeben.... «.40)

I de dele af Sønderjylland, som hørte under Slesvig stift, var den almindelige regel, at øvrigheden (hertugen $i$ den gottorpske og amtmand og provst $i$ den kongelige del) præsenterede, og menigheden kaldte. ${ }^{40}$ a) Saa vidt det noget knappe materiale viser, har denne regel dog ikke i ældre tid haft gyldighed for de gottorpske sogne i Vestslesvig. Det var menigheden eller kirkeværgerne og andre repræsentanter for sognet. som valgte og kaldte den unge mand til præst. Dog skulde amtmand og provst give deres tilladelse til kaldelsen eller $\mathrm{i}$ hvert tilfælde til, at kandidaten holdt prøveprædiken for menigheden. Da Andreas Hansen Gaansager i $1581 \mathrm{blev}$ kaldet til sognepræst i Ubjærg, hedder det i kaldsbrevet, som de to kirkeværger og otte andre mænd udstedte "wegen des gantzen Caspels Ubargh", at disse har kaldet og æsket ham med amtmandens og provstens "vorloff, consent und bevulwordung (d. v. s. tilladelse) «.Og lignende udtryk kommer igen flere gange. ${ }^{41}$ ) Da der i 1681 var vakance i Rabsted sogn, præsenterede hertugen Peter Petersen til det ledige embede. Amtmanden og provsten, der ønskede Tycho Thomsen ${ }^{42}$ ) som præst i sognet, protesterede herimod, da denne fremgangsmaade stred imod de regler, man ellers almindeligvis fulgte ved præstebesættelser i Tønder og Løgumkloster amter, hvor det var sæd og skik, at kandi-

40) Top. Hadenslev Amt: (1434-1748) "Copiale von Priv. und Verordn. p. p..... 319 f.

${ }^{40}$ a) Feddersen: Kirchengeschichte Schleswig-Holsteins II $401 \mathrm{f}$.

${ }^{41}$ ) Acta A. XX. 2170 (Ra.); C. V. 145; Tønder Provstearkiv: Ubjærg: "Verwaltung des Pastorats, Vakanzen, Wahlen, Vikarierung, Emeritierung«; Acta A. XX. 2574 (Ra.); Højst Præstearkiv: B. d. 1, 1589-1900 Forskellige Breve og Dokumenter.

42) Født den 6. februar 1652 i Tønder som søn af Thomas Tychsen, bykæmner, deputeret borger og handelsmand i Tønder og Christina Rasch (datter af Lorentz Rasch, kirurg i Tønder), gift den 27. juni 1682 i Rabsted med Dorothea Catharina, ældste datter af pastor Tamm i Preetz. Han var fra 1681 og til sin død i 1708 præst i Rabsted. En udførlig levnedsbeskrivelse af ham findes i Tønder Provstearkiv: Rabsted: "Verwaltung des Pfarramtes, Vakanzen, Wahlen, Vikarierung, Emeritierung«. 
daten først henvendte sig til de to høje herrer, hvorefter han af dem blev »... mit einem förmblichen præsentation-Schreiben an die vacante Gemeine dahin abgefertiget, dass er bey gemeiner Versamblung in einer Probpredigt an dem dazu bestimbten Tage sich hören. lassen, und dieselbe, wann sie wieder dessen Person und Gaben nichtes einzuwenden haken, ihm die vocation in Schrifften ertheilen.... $\ll^{43}$ ). I virkeligheden er denne fremgangsmaade næppe væsentlig forskellig fra den ovenfor skildrede. Om man kalder amtmandens og provstens tilladelse til at holde prøveprædiken for en præsentation eller ej, er ikke det afgørende. Det springende punkt er, om de kunde bestemme, hvem der kunde lade sig høre for menigheden. Følgende sag synes at vise, at det ikke har været tilfældet.

I 1650 søgte Paulus Petræus embede. Han blev da raadet til at holde en gæsteprædiken i Højer, hvor der var vakance, ".... welches der $\mathrm{H}$. Ambtman ungern bewilligt wegen des $\mathbf{H}$. Pastoris Sohn in Braderup, der sich hören lassen, aber mit geringer Beliebung der Zuhörer. Weil er's aber nicht abschlagen können auf mündliche Conferierung mit dem Herrn Praeposito, als habe ich den 27. Oct. meine erste Probpredigt .... gehalten .... Darauf Ich den ordentlicher Weise von allen kegenwärtigen Zuhörern zu ihrem Seelsorger ordentlich und ohne Jemandes Kegenstand bin vociret worden.... . $^{44}$ )

Menighedens Kaldsbrev skulde anerkendes af hertugen eller af amtmanden, eventuelt af amtmanden og provsten paa dennes vegne. Inden prøveprædikenen skulde den vordende præst eksamineres af provsten i Tønder, og inden den endelige tiltrædelse af embedet af generalsuperintendenten. ${ }^{45}$ )

I det 17. aarhundrede gik udviklingen stadig henimod et stærkere centralstyre. Dette gjorde sig ogsaa gældende med hensyn til præstevalgene. Ligesom i Tørninglen søgte myndighederne at skaffe sig indflydelse herpaa gennem præsenta-

43) Acta C. VI. 2, 666.

44) Rolfs: Geschichte des Kirchspiels und Fleckens Hoyer 91.

45) Acta A. XX. 2170 (Ra.); Rolfs: anf. sted 86, 91 f.; Feddersen: anf. sted 403 ff.; Acta C. VI. 2. 666. 
tionen af valgkandidaterne for menigheden. Da rektoren i Tønder Johannes Mauritzen var blevet præsenteret til, præst i Brede, satte nogle af sognets beboere sig derimod. De vilde først høre andre kandidater og holdt paa deres valgret. Men hertug Frederik tog intet hensyn dertil. Amtsskriveren i Logumkloster fik den 8. januar 1633 ordre til at sørge for, at præsten blev indsat $i$ embedet, "... wann uns das jus patronatus ohne allen streit ganzig und allein zustehet.... . Nogen modsigelse hverken vilde eller kunde hertugen taale. $\left.{ }^{46}\right)$ Muligvis kan forholdene i Brede have været noget egenartede, idet denne kirke oprindelig hørte til Løgumkloster.

Iøvrigt haves der allerede fra en tidligere tid et eksempel paa, at den gottorpske regering umiddelbart har besat et præstekald paa disse egne. Den 30. november 1611 udstedte hertugen et brev om, at Lorentz Boysen, præst i Løgumkloster, skulde have præsteembedet i Nørre-Løgum ("hinwieder bestellet und angenommen werden soll «. $\left.{ }^{37}\right)$. Forholdene var her noget særegne, idet den paagældende altsaa allerede var præst i Logumkloster, der dog dengang ikke var et særligt sogn, men udgjorde en del af Norre-Løgum sogn. Ogsaa denne kirke havde hørt til klostret.

I løbet af det 17. aarhundrede fuldbyrdedes denne udvikling, og omkring 1700 var forholdet nogenlunde det samme som i Haderslev amt. Det var nok sognemændene, der valgte og kaldte, men faktisk synes den frie valgret, som de tidligere havde haft, at være blevet indskrænket ved, at amtmand og provst bestemte, hvem der skulde lade sig høre for menigheden. ${ }^{48}$ Da det ikke altid er let at afgøre, hvad begrebet præsentation til de forskellige tider dækker over, er det dog vanskeligt med absolut sikkerhed at fastslaa, hvordan de faktiske forhold har været.

16) Acta A. XX. 2169 (Ra.).

17) Acta A. XX. 2170 (Ra.).

4) Se for eksempel kaldsbrev for Chr. Wegner i Ubjærg $17012 / 6$ (Acta A. XX. 2574 i Ra.) og oplysningerne 1709 fra Højst (Højst Præstearkiv: B. d. 1. 1589-1900 Forskellige Breve og Dokumenter). 
I de sogne, hvor en privatmand eller institution havde kaldsret, var fremgangsmaaden ved valgene selvfølgelig noget anderledes end i de kongelige og hertugelige sogne. Det var her patronatsejeren, der direkte kaldte præsten. Dog havde menighederne ogsaa en vis, indflydelse paa valget, idet de almindeligvis hørte den vordende præst prædike, inden kaldelsen fandt sted. Fra Brøns sogn haves endda et eksempel paa, at 10 mænd 1628 paa sognets vegne kaldte en præst, Jens Pedersen, som nogle gange havde ladet sig høre paa prædikestolen, hvorefter de anmodede ærkedegnen om at konfirmere valget. ${ }^{40}$ ) Iøvrigt skulde ogsaa disse privat kaldede præster eksamineres af biskoppen $i$ Ribe og have testimonium frá universitetet $\mathrm{i}$ København. ${ }^{50}$ ) Da Anna Rantzau i 1629 kaldte Hans Rasmussen til embedet i Visby, bad hun biskoppen, om han ikke under de vanskelige forhold maatte blive fri for at rejse til København for at faa sit testimonium. ${ }^{51}$ )

I Vestslesvig fandtes den private patronatsret fra gammel tid i de sogne, hvis kirker var annekteret kapitlet i Ribe: Brøns, Emmerlev, Ballum, Farup og Vester-Vedsted. Det sidste embede var forenet med lektoratet i Ribe, og sædvanen var, at kapitlet kaldte byens rektor hertil. Saaledes gjorde man ogsaa ved vakancen i 1664. Rektoren mester Hans Rosenberg lod sig derefter høre af menigheden og blev eksamineret af biskoppen. Ordinationsdagen var allerede fastsat. Men inden man naaede saa vidt, kom der brev om, at kongen havde forordnet konrektor i København mester Gregers Christensen til lektoratet. Det var atter et eksempel paa, hvordan den enevældige konge greb direkte ind ved besættelsen af de gejstlige embeder. Gregers Christensen fik embedet, men døde allerede nogle faa uger senere. Hans efterfølger blev Anders Bording, digter og udgiver af "Den danske Mercurius«. Først da han, der var journalist,

4) Trøjborg Godsarkiv: Pk. 8. Kirker og Skoler; Ribe Bispearkiv: Hviding Herred: Ad Reg. Nr. 7, Capsa 16, Pk. 1 (V.).

so) For eksempel Fr. Koch 1655 (Trøjhorg Godsarkiv: Pk. 8. Kirker og Skoler).

51) Ribe Bispearkiv: Indk. Breve $1569-1685$ (V.). 
ikke præst, trak sig tilbage, fik Hans Rosenberg lektoratet og dermed præsteembedet i Vester-Vedsted. ${ }^{52}$ )

Til de fire kirker i Lø herred: Visby, Døstrup, Mjolden og Randerup fik Peder Rantzau i 1579 jus patronatus. ${ }^{53}$ ) Peder Rantzau var en af datidens stridbareste og haardeste mænd, som for voldsomt frem mod sine undergivne og stejlt søgte at udnytte alle sine rettigheder, undertiden saa stærkt, at han kom paa den forkerte side af loven. ${ }^{54}$ ) Hans erhvervelse af patronatet gav ogsaal anledning til strid. Kapitlet i Ribe vilde ikke finde sig $i$, at han skaltede og valtede med de fire kirkers indkomster, som det passede ham. Sagen procederedes for herredsting, landsting og herredag. Dommen gik Peder Rantzau imod, og han maatte give kirkerne 3300 daler og opgive ethvert krav paa dem. ${ }^{55}$ )

Men kaldsretten havde han i behold. Et par breve fra Trøjborg godsarkiv belyser nærmere forholdet mellem patron og præst. I 1590 blev mester Andreas Jacobsen, der havde været diakon i Skærbæk, kaldet til præst i Visby, og den 2. februar 1591 indgik han en kontrakt med Peder Rantzau. Han fik foruden de almindelige afgifter løfte om 60 mark lybsk fra Trøjborg og seks ørtug korn og en eng paa Mollerup mark samt en velbygget bolig og et fuldt gods (gaard) i mark og eng. Paa den anden side maatte han forpligte sig til ikke at modtage kald andetsteds og til selv at holde præstegaarden $i$ stand.

Rantzauerne tilhørte en holstensk adelsslægt. Deres sprog var tysk, og præsten i Visby maatte derfor være i stand til ogsaa at prædike paa tysk. Da Frederik Koch i 1655 blev kaldet af Daniel Rantzau maatte han derfor først holde en tysk prædjken for slotsherren og hans »beihabende Gesinden« og deref-

52) Kragelunds Kopibog 194 f.; Arends: anf. sted III 104, I 67.

53) Nye kirkehistoriske Samlinger I $85 \mathrm{ff}$; jvnf. Kronens Skøder I $217 \mathrm{og}$ Jyske Samlinger 4. r. IV $101 \mathrm{ff}$; Ribe Bispearkiv: Lø Herred, Ad. Reg. 17, Capsa 18, Pk. 11.

s4) Se for eksempel Kancelliets Brevbøger 1586 26/6, 1587 13/3.

s5) Secher: Samling af Kongens Rettertings Domme I $176 \mathrm{ff}, 242 \mathrm{f}$; Jyske Samlinger 4. r. IV 101 f.; Ribe Bispearkiv: 1598 21/6 (Pergamenter). 
te:1 en dansk for menigheden. ${ }^{56}$ ) Tyske indvandrere til Sønderjylland har sjældent udmærket sig ved sprogtalent, og den tysktalende' præst i Visby øvede tiltrækning paa de tyske adelsmænd i omegnen, der ikke evnede at tilegne sig landets sprog. Paa Søndergaard i Emmerlev boede i 1632 Caspar Rudolf Gerstorff. Han og hans kone var begge, efter hvad der oplystes, tysk fødte og ønskede derfor at blive betjent af Visby præsten, der kunde tysk, hvad hans kollega i Emmerlev ikke kunde. ${ }^{57}$ )

Foruden Trøjborg havde ogsaa Schackenborg og Gram kaldsret til flere kirker. Den 1.november 1661 erhvervede rigsfeltherren Hans Schack kaldsretten til Møgeltønder, Daler, Ballum, Rømø, Vesterlandsfør og Amrum kirker, og da grevskabet i 1673 erigeredes, kom hertil Emmerlev kirke, der tidligere, sammen med Brøns kirke, havde været annekteret ærkedegnen i Ribe. ${ }^{58}$ ) Erkedegnen havde tidligere haft indfæstningspengene af kirketienderne og kirkejorderne i Møgeltønder, Daler og Rømø, ligesom ogsaa visse indtægter afl Ballum. Overdragelsen betød derfor afgang i hans indtægter, hvorfor han af det vakante kantoratsembede fik udlagt en indtægt paa 70 tønder korn og fem fjerding smør til vederlag. ${ }^{59}$ )

Hans Schack ejede ogsaa Gram gods, og sammen med Emmerlev erhvervede han Gram og. Fole kirker. ${ }^{60}$ ) Ialt 12 kirker i det her behandlede omraade har saaledes været underkastet den private kaldsret.

\section{Landemodet:}

I middelalderen indtog gejstligheden en meget fremtrædende stilling, politisk saavelsom okonomisk og kulturelt. Den var næsten en stat $i$ staten. Det var derfor naturligt og iøvrigt i overensstemmelse med datidens synsmaade, at den hav-

56) Trøjborg Godsarkiv: Pk. 8. Kirker og Skoler.

57) Ribe Bispearkiv: Indkomne Breve 1569-1685. (V.).

$\left.{ }^{58}\right)$ Kronens Skøder II 110,404 f; junfr. Sønderjydske Aarbøger 1910. 187, $200 \mathrm{og} 214$ samt 1930. 64; Kinch: anf. sted II 510.

s9) Kragelunds Kopibog 140 f, $178 \mathrm{ff}$.

$\left.{ }^{60}\right)$ Kronens Skøder II 405. 
de sin egen ret til at afgøre indbyrdes stridigheder eller til, at dømme folk, som var kommet i strid med kirkens bestemmelser. Selvom gejstlighedens stilling ved reformationens indforelse med et slag forandredes, blev dette forhold dog i det væsentlige ved at bestaa. I ribeartiklerne af 1542 hedder det, at kapitlet havde jurisdiktion i ægteskabssager, men der findes adskillige og uigendrivelige vidnesbyrd om, at denne til domkirken knyttede kreds af gejstlige ogsaa sammen med stiftslensmanden havde jurisdiktion $i$ almindelige gejstlige sager.

I Sjællands stift og andre steder var der nogen tid efter reformationen blevet indfort gejstlige landemoder med domsmyndighed i disse sager. Ved kongelig forordning af 1. maj 1618 indførtes der landemoder i hele landet. Egteskabssager skulde dog stadig høre under kapitlet. I Ribe stift skulde der aarlig holdes to landemoder, det ene i Ribe tre dage før st. Hans, det andet $i$ Varde kort før jul. I 1649 afskaffedes mødet i Varde, da man beklagede sig over vanskeligheden ved at rejse paa denne aarstid. Men stiftet var dog for stort og sagerne for mange til, at man kunde nøjes med den ene sammenkomst, og i 1655 genindførtes den gamle tingenes tilstand. Tiderne blev dog nu forandret til onsdag efter anden søndag efter paaske (i Ribe) og onsdag efter Dionysii dag, den 9. oktober (i Varde). ${ }^{\text {in }}$ )

For landemodets medlemmer - stiftslensmanden, der førte præsidiet, biskoppen og provsterne - oplæstes formaninger til gejstligheden, de saakaldte synodalmonita. Foruden af landemodet kunde retstrætterne ogsaa, som det fremgaar af landemodeprotokollen, afgøres af biskoppen selv, eventuelt i forbindelse med Ribe bys gejstlige. Forhandlingerne kunde i saaaanne tilfælde foregaa forskellige steder, ofte i kapitlets eller biskoppens hus, men undertiden ogsaa hos lensmanden, engang saaledes win arce Haderslebiense (paa Haderslevhus). Lens-

a1) Kirkehistoriske Samlinger 2. Række, VI 652 ff.; Kinch: Ribe Bys Historie og Beskrivelse II $488 \mathrm{ff}$. 
manden skulde overvære behandlingen af de gejstlige sager, og flere gange fandt der udsættelse sted, fordi han ikke kunde være til stede, i andre tilfælde sendte han en repræsentant. Da Ribe stift var meget stort - det omfattede sogne fra Limfjorden til Tonder, fra Lillebælt til, Vesterhavet -- var provsterne ikke altid begejstret for den lange og besværlige rejse. Ofte mødte de ikke frem paa landemodet og sendte heller ikke en repræsentant i stedet. I 1662 maatte biskoppen skarpt reprimandere de herrer provster. De fik en streng paamindelse om, at mødte de ikke eller en af herredet for dem, skulde de bøde fire rigsdaler. Det fastsloges endvidere, at den ældste præst i herredet skulde være provstens stedfortræder, og at præsterne, saaledes som sædvanen var paa Sjælland og andre steder, skulde bidrage til provstens rejse, mindst med to mark hver. ${ }^{.2}$ )

Trods disse bestemmelser kunde det dog ofte være vanskeligt at faa en stedfortræder til at tage afsted. I 1684 kunde herredsprovsten i Hviding herred ikke komme til landemodet i Varde. Han havde lovligt forfald. Han bad herredets præster overlægge, hvem af dem, der skulde rejse derop i hans sted. Men alle undskyldte de sig. Ingen af dem havde disponeret deres sager derefter, "... hvorfor hr. Herredsprovsten vilde os for dene vidtløftige rejse forskaane....« og undskylde dem hos biskoppen. ${ }^{.3}$ )

Et referat af de forhandlinger, der førtes paa landemodet eller synoden, som mødets navn ogsaa var, indførtes i en protokol, som for Ribe stifts vedkommende først er bevaret fra 1635. $\left.{ }^{.4}\right)$ Synodalmonita findes ogsaa heri. Protokollen er ført paa latin og dansk og er som regel ført i pennen og antagelig ogsaa redigeret af biskoppen selv. Som oftest er monita paa latin og referaterne af sagerne paa dansk.

62) Landemodeprotokollen $198 \mathrm{f}$.

4) Ribe Bispearkiv: Indkomne Breve 1569-1685 (V.).

-4 Landemodeprotokollerne findes i Ribe Bispearkiv (V.). 


\section{Gudstjeneste og kirkelige handlinger:}

Altergangen har for den kristne kirke altid været af stor betyłdning - derfor ogsaa i kirkens historie et af de store stridsspørgsmaal. Den katolske kirke, Luther og Calvin stod her skarpt imod hinanden. Det var derfor forstaaeligt, at man strengt skred ind mod den, der ikke administrerede dette sakramente paa tilbørlig vis eller ikke viste tilstrækkelig ærbødighed over for brødet og vinen. Mester Ingvard Mulvad i Ballum maatte sande dette. For landemodet' stod han anklaget for at have brugt ukonsekreret brød ved altergangen. Sagen havde være behandlet adskillige gange og ogsaa været for den verdslige ret, landstinget i Viborg. Og landets ypperste teologer, selve det teologiske fakultet og den gamle biskop Resen, landets forste prælat, havde afgivet betænkning' i sagen. Mester Ingvard havde . været suspenderet. Men vidnerne stemte ikke overens. Saaledes svarede degnen i Ballum Jens Jacobsen benægtende, da han blev spurgt, om han med god samvittighed kunde sige, at sognepræsten havde brugt ukonsekreret brød ved altergangen paa pinsedag. Det maatte »være Gud og mester Ingvard imellem . $^{65}$ ) Den 18. marts 1638 afsagdes kendelsen: Mester Ingvard fik atter lov at vende tilbage til sit embede og sin prædikestol, da fakultetet mente, at han ikke burde miste kaldet, naar det ikke ved vidnernes ed kunde fastslaaes, at han havde brugt ukonsekreret brød, og landsdommeren ikke havde villet kende vidneudtalelserne ved magt paa grund af deres uoverensstemmelse. Dog skulde Ballums sognehyrde for sin uagtsomhed give 30 slettedaler til fattige gejstlige enker efter Kongelig Majestæts ordinans. ${ }^{68}$ ) Desuden skulde han alvorlig paamindes angaaende sakramentets uddeling. ${ }^{.7}$ )

I 1647 begik den unge Hans Detlefsen Froem i Arrild et ".... missetrin.... med vin' for brød at udgive uformodent-

B5) Landemodeprotokollen 25 ff.

o6) Forordningen af 16. juni 1637 (H. F. Rørdam: Danske Kirkelove III $260 \mathrm{ff}$.).

. ${ }^{67)}$ Landemodeprotokollen 25 f., 30. 
lig.... H. Hans sognebørn erklærede, at han havde forholdt sig kristelig og vel, og at de var tilfreds med ham. De bad om, at han ikke maatte blive straffet for strengt. Ved kongens brev slap han med aarlig at betale renten af 100 rigsdaler in specie til Skrydstrup kirke samt et aars suspension. ${ }^{68}$ )

Præsterne havde ofte et bestemt beløb eller indtægten af en eller anden jord til at dække udgifterne til brød og vin. Omkring 1600 fik præsten paa Rømø otte mark aarlig hertil, mens præsten i Abild i 1650 fik 30 mark og præsten i Visby i 164310 mark lybsk. I Skast havde præsten 15 skæpper byg af en af kirkens jorder, hvoraf der ialt blev givet to ortug og tre skæpper korn. ${ }^{69}$ ) I mange tilfælde var en vis del af kirketienden henlagt til brød og vin. I Døstrup saaledes fire ørtug korn og i Randerup to ørtug. ${ }^{70}$ ) I Ubjærg maatte præsten af sin egen pung betale udgifterne til brød og vin. Forst 1736 fandt man det ubilligt, at han skulde være daarligere stillet end alle de andre præster, og der blev tillagt ham et beløb paa 15 mark lybsk aarlig. $\left.{ }^{1}\right)$ Et saadant fastsat beløb kunde selvfølgelig medføre den fare, at præsten ikke onskede alt for mange kommunikanter. I 1647 stævnedes Thomas Høst i Hviding til biskoppens hus i Ribe efter begæring af amtmanden i Haderslev: Han skulde have sagt nogle uoverlagte og strafværdige ord til sine tilhørere: de skulde ikke saa meget og saa tit gaa til Guds bord, thi han fik kun faa penge for bred og vin. $\mathrm{Hr}$. Thomas svar synes at være noget undvigende: der var ingen, der kunde bevise, at han nogensinde havde forvist nogen fra. Guds bord af denne grund. Men han nægtede ikke at have søgt at faa folk til at komme til afløsning om lørdagen, ». . paa

*) Ribe Bispearkiv: Reskripter 1637-1666 (V.); Hviding Herreds provsts Arkiv: "Prouste Bog udi Huidding Herret" 1649; Schriften des Vereins für Schleswig-Holstenische Kirchengeschichte 2. r. VII 513.

$\left.{ }^{6}\right)$ Ribe Bispearkiv: Archidiakonatets Kirkeregnskaber for Lø $\mathrm{m}$. fl. Herreder 1554-1660; Skast Kirkeregnskabsbog 1638-1861 (Skast Præstearkiv).

1649-1785. $\left.{ }^{71}\right)$ Ubjærg Præstearkiv: C. c. 1. 1581-1906 Kirkeinventarier og forskellige Efterretninger og Indberetninger. 
det han vin og brød kunde have til nødtørftighed udi god for$\operatorname{raad} \ldots \ll^{72}$ )

Iøvrigt forekommer det flere gange, at præsterne stævnes til landemodet, fordi de ikke har villet give folk adgang til skriftestolen og til sakramentet. Søren Pedersen Hegelund i Skærbæk var kommet i voldsom strid med familien Spandet, blandt andet fordi det hævdedes, at præsten ved en privat aflosning af Peder Spandet ikke havde brugt haandspaalæggelse, som han skulde: efter ordinansen. Da Peder Spandet og hans kone en søndag blev afvist fra delagtighed i alterens sakramente, kom det ligefrem til oprør i Skærbæk kirke. Striden stod paa i flere aar. Først efter at et kongebrev, dateret 16. Februar 1646, havde paabudt amtmanden i Haderslev og biskoppen i Ribe at fælde en endelig kendelse i striden, saa at kongen $» . .$. for deres daglige overløb kan være forskaanet ....«, lykkedes det at faa et forlig i stand. Skærbækpræsten maatte under sit kalds fortabelse love at forbedre sig og afholde sig fra klammeri og kiv, trætte og skældsord. Han skulde betale biskoppen 100 mark og Peder Spandet 30 mark for kost og tæring. ${ }^{73}$ )

Ni aar senere var han dog atter i strid med et medlem af familien Spandet, idet han holdt Karen Spandet borte fra sakramentet. ${ }^{74}$ ) Udelukkelse fra absolutionen og sakramentet brugtes iøvrigt overfor folk, der havde begaaet overtrædelser af kirkelig art. En mand i Randerup, der var blevet udlagt til barnefader, dømtes saaledes til at afholde sig fra privat absolution, indtil "... han sig det lovligen fraligger, at man ikke saa løseligen med menighedens store forargelse med slige sager skal omgaaes $\left.\ldots . \ll_{.^{75}}\right)$.I 1650 forviste Bertel Sture i Hjortlund-Kalvslund en mand fra skriftestolen, fordi han paa mange

72) Landemodeprotokollen 89 f.

$\left.{ }^{73}\right)$ Kongens brev $i$ Ribe Bispearkiv: Hviding Herred: Ad Reg. Nr. 7, Capsa 16, Pk. 6; jvnfr. iøvrigt Sønderjydsk Maanedsskrift 1936. 109 ff.
74) Landemodeprotokollen 129.
${ }^{75}$ ) Landemodeprotokollen 109. 
maader havde overtraadt moralens bud. I Brøns turde præsten i 1685 ikke til privat absolution modtage en mand, der i næsten et aar ikke havde været til alters, fordi han sommeren over havde været i Grønland, som det synes paa skib fra Hamborg. Præsten raadede ham til at angive sig for biskoppen og berette sagen for denne. ${ }^{76}$ )

Det var i ældre tid almindeligt, at børnene blev døbt meget hurtigt efter fodslen. Ved forordningen af 23 . maj $1646 \mathrm{blev}$ det under 10 rigsdalers bøde til nærmeste hospital forbudt at udsætte daaben mere end otte dage. ${ }^{77}$ ) Anne Rantzau paa Irøjborg maa daabens vigtighed have ligget stærkt paa sinde. Den 15. januar 1641 stod Jens Andersen, kirkeværge i Mjolden, in!dstævnet, fordi hans barn var død uden at blive døbt af præsten. Barnet havde været raskt ved fødslen, men da det var nogle dage gammel, blev det pludselig sygt. Man kunde ikke naa at faa hentet præsten, men fik fat i nogle nabokvinder, som døbte barnet i faderens, sønnens og den helligaands navn. Fru Anne Rantzau, patron for Mjolden kirke, fik nys om sagen og lod sin delefoged befale provsten, at han skulde give biskoppen underretning om det skete, idet hun mente, at manden burde straffes, fordi han ikke i rette tid havde ladet barnet komme til daaben og ikke, da det blev sygt, havde hentet præsten, der boede $\mathrm{i}$ byen. Kvinden, der oste vand paa barnet, mente hun ogsaa burde straffes, fordi hun ikke havde gjort det straks efter, at barnet blev født. ${ }^{78}$ ) Da de nærmere omstændigheder ikke var fuldt oplyst, lod landemodet Jens Andersen slippe for straf, men en paamindelse om at have flittigt opsyn med, at der ingen forhaling skete med hans børns daab, fik han da med hjem. ${ }^{79}$ )

Tidligere tiders angst for indgifte, for ægteskab mellem nær beslægtede, var meget stærkt udviklet. Og saa var de

76) Ribe Bispearkiv: Indkomne Breve 1569-1685 (V.).

77) H. F. Rørdam: Danske Kirkelove III $328 \mathrm{f}$.

78) Ribe Bispearkiv: Af Archidiakonatets Breve og diverse Dokumenter $1562-1695$.

${ }^{70}$ ) Landemodeprotokollen 51. 
strenge bestemmelser fra katolicismens tid endda blevet lempet. Dengang havde ægteskab været forbudt mellem mennesker, der havde staaet fadder ved det samme barns daab. Indtil Struensees tid var slægtsskab mellem mennesker, der var beslægtet i tredie led (næstsøskendebørn), forbudt uden særlig tilladelse fra myndighederne. Præsterne maatte for ikke at komme til at forse sig have god rede paa deres sognebørns slægtskabsforhold, og let kunde de komme til at begaa fejl. Søren Hegelund i Skærbæk, landemodets smertensharn, var nær kommet galt af sted. Det var i 1663, da han havde været præst i en 34 aar og altsaa maa antages at have været fortrolig med en præsts embedspligter, at biskoppen efter amtmanden i Haderslev Cai Ahlefeldts befaling lod ham fremkalde i synodet, fordi han havde forrettet en trolovelse mellem en mand af Riberhusstavn og en kvinde af Haderslevhus stavn, som var beslægtet $i$ tredie led. Hr. Søren kunde dog klare for sig: han fremlagde en tilladelse fra grev Schacks fuldmægtig til at vie dem. Men forrette vielsen af parret maatte han ikke uden tilladelse fra øvrigheden, og denne, d. v. s. amtmanden i Haderslev, forbød, endda $i$ kongens navn, at foretage vielsen. Grunden var, synes det, at man ikke havde ansøgt om dispensation ved Haderslev amt. Hele sagen var et udslag af de altid ulmende kompetencestridigheder mellem Ribe og Haderslev..$^{80}$ )

I 1647 maatte præsten i Brøns give møde i Ribe, fordi han imod et forbud havde trolovet kapellanen i Hviding, Thomas Henriksen, og en datter af Hans Andersen i Havervad, herredsfoged i Hviding herred. ${ }^{81}$ ) Grunden til forbudet var, at præsten i Hviding mente, at kollegaen kun maatte trolove sine egne sognefolk eller dem, der kom med vidnesbyrd om at maatte trolove sig med hvem, de onskede. Dommen gik ud paa, at præsten i Brons havde forbrudt sig mod den kongelige forordning og skulde søge Kongelig Majestæts "hyldest og

$\left.{ }^{80}\right)$ Landemodeprotokollen 225 f.; Kragelunds Kopibog 168 f.; Acta A. XVII. 802 (Ra.).

81) Denne, der tilhørte en kendt herredfogedslægt, var svigerfader til flere præster i Vestslesvig (Sønderjydsk Maanedsskrift 1936. 106). 
naade«. Sagen ordnedes dog med en bøde paa 10 rigsdaler til fattige præsteenker. ${ }^{82}$ )

Den kirkelige straf overfor dem, der havde forset sig mod religionens og moralens bud, var forst og fremmest det offentlige eller aabenbare skrifte, hvor synderen i menighedens paasyn og paahør maatte fortælle om sin synder. Mest var det forseelser mod det sjette bud, som der skulde skriftes for. Overtrædelser af dette bud forekom ogsaa dengang, selv om knapt saa hyppigt som nu. Efter en beregning, foretaget af kulturhistorikeren Gustav Bang, var gennemsnitligt 8,4 pCt. af de i perioden 1645-1699 i Danmark fødte børn avlet udenfor ægteskab, i perioden 1926-1930 var procenttallet $10,9 \mathrm{pCt}^{\mathrm{83}}$ ) Normalt var saadanne forseelser oplagt. Tvivl kunde dog ogsaa opstaa. I 1656 havde et ægtepar i Hviding af præsten været suspenderet fra sakramentet, fordi konen var nedkommet seks uger for tidligt. Men da de for biskoppen aflagde ed paa, at de ikke havde haft legemlig omgang med hinanden før vielsen, fik præsten paabud om at modtage dem til sakramentet. ${ }^{84}$ ) I andre tilfælde, som i og for sig var oplagt, gik præsten selv i forbøn for dem, der havde forbrudt sig. Saaledes engang præsten i Døstrup Mikkel Andersen. En mand var blevet gift for tredie gang. Hans kone var kommet i barselseng otte eller 10 uger for tidligt. Fruen paa Trøjborg, Anne Rantzau, viste denne gang mere menneskelig forstaaelse og medlidenhed end $\mathrm{i}$ sagen mod Jens Andersen i Mjolderr. Hun benaadede manden, vilde ikke beskæmme og skatte ham derfor, gav afkald paa den bøde, der kunde tilkomme hende. Præsten spurgte biskoppen, hvordan han skulde forholde sig i sagen og lagde et godt ord ind for lovovertræderne. Han saa ikke gerne, at de fattige folk skulde beskæmmes. Iøvrigt oplyste han, at i biskop Iver Hem-

82) Landemodeprotokollen 94 f.; Ribe Bispearkiv: Hviding Herred: Ad Reg. Nr. 7, Capsa 16, Pk. 1 (V.); Indkomne Breve 1569 1685 (V.).

83) Gustav Bang: Kirkebogsstudier 70; Statistisk Aarbog 1935. 22.

84) Landemodeprotokollen 141; jvnf. 228, hvor en sag af samme art fra Vester-Vedsted fik samme udfald. 
mets tid var en lignende sag i Randerup blevet ordnet i stilhed og uden beskæmmelse for de paagældende: $:^{85}$ )

Men ogsaa for andre forseelser kunde man blive dømt til at staa offentligt skrifte. En mand i Toftlund, som "... af overflødighed og drukkenskab $i$ en ligprædiken haver menigheden til forargelse overgivet sig .... «, skulde med det første offentligt afbede sin synd i menigheden. ${ }^{83}$ ) 1637 forpligtede en anden mand sig til at indstille sig til aabenbar aflasning. Gjorde han det ikke, skulde sognepræsten procedere efter kirkedisciplinen og paa tre søndage lyse ham til bands; hvis det saa ikke hjalp, skulde han endelig bandsættes. ${ }^{87}$ ) En mand, der af kirken var sat $i$ band, var paa en maade en udskudt, staaende udenfor de hæderlige og agtværdiges samfund. Sakramentet var ham forment, og han maatte ikke indbydes eller komme til noget hæderligt samkvem. Han kunde faa adgang til at høre Guds ord i kirken, men skulde der "have særdeles et sted for sig “. Vilde han alligevel ikke bøje sig, skulde han stævnes for landemodet, "... og da ved dom sit herskab at overantvordes og siden af vore lande og riger at forvises .... . $^{88}$ )

\section{Præsternes moralske vandel:}

Det er kendt, at man i tidligere tid drak meget stærkere end nu om dage. og drukkenskab og beruselse hørte nærmest til dagens orden. Betegnende er det saaledes, at man i Aabenraa $i$ begyndelsen af det 17 . aarhundrede fastslog, at fogden skulde holde ting "gut zeitt tages«, for at parterne kunde mode ædru paa tinge ${ }^{89}$ ) Men med præster var det selvfølgelig noget andet. For deres vedkommende kunde selv en let rus ikke gaa an. De skulde staa som eksemplet for menigheden. Skete det, at "... nogen præst befindes saa beskænket, at (han) ikke

85) Ribe Bispearkiv: Af Archidiakonatets Breve og diverse Dokumenter 1562-1695.

86) Landemodeprotokollen 126 .

87) Landemodeprotokollen 19.

88) H. F. Rørdam: Danske Kirkelove III $149 \mathrm{f}$.

89) Aabenraa Byarkiv: Claus Esmarchs Optegnelsesbog. 
kunde gøre sit embede (hvad heller han fordres til nogen eller ikke) uden forargelse, da skal han straks uden videre paamin-

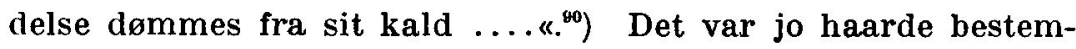
melser, og skulde de være opfyldt til punkt og prikke, var der sikkert mangen en god og agtværdig præstemand, der havde maatte opgive præstegerningen. Men biskop og provster var cgsaa mennesker. Ogsaa de har vel kendt lidt til de mere verdslige glæder, har vidst, at $\mathrm{i}$ vinen og brændevinen kunde et menneske glemme sorger og bekymringer for en stund, og erkendt, at selv en kirkens mand som menneske kunde have en ret til at søge denne trost, naar verden stod ham for haardt imod. I den her behandlede periode var der ingen præst $i$ Vestslesvig, der blev dømt fra embedet af den grund. I de tilfælde, hvor sager af denne art behandledes, slap de paagældende med skarpe paamindelser. $\mathrm{Og}$ dog var det alvorlige beskyldninger, som i 1642 rejstes mod kapellanen i Skærbæk, Thomas Buck. Da han midt under gudstjenesten kom tilbage til kirken efter on lille udflugt paa naturens vegne, gik han ravende op ad gulvet. Senere forstyrrede han Peder Skrædder i sangen under messen. Under prædikenen havde han ikke blot sovet, men han havde snorket, saa man kunde saa godt som hore det i prædikstolen. ${ }^{41}$ ) I 1639 var det sognepræsten i Spandet, Peter Johansen, der stod anklaget for at have været drukken ved gudstjenesten. Nu havde pastoren fornylig været syg, og han havde forskaffet tingvidne og sognevidne paa, at det var sygdommen, der var skyld i kalamiteten. Biskoppen havde ved visitatsen selv forhørt menigheden, som alle excuserede ham. Det blev saa til, at han alvorlig og whaardelig* blev paamindet om at være ædru og afholdende, ellers vilde han snart være uden embede. ${ }^{02}$ ) Men paamindelsen hjalp ikke. Otte aar senere er det galt igen med Hr. Peter, og saa havde biskoppen endda selv ved visitatsen i Spandet kirke 1646 paamindet ham

\footnotetext{
90) H. F. Rordam: Danske Kirkelove III 267.

91) Landemodeprotokollen $64 \mathrm{f}$.

22) Landemodeprotokollen 34 .
} 
om at føre et ædrueligt og skikkeligt levned. Denne gang var det ikke blot brændevinsflasken, han kikkede for dybt i; han gav sig ogsaa hen til tobaksdrikken. Det kunde have været kulturhistorisk interessant at faa lidt nærmere at vide om, hvordan dette gik for sig. Mærkeligt lyder det i hvert fald. Den Spandet præst synes imidlertid ikke at være kommet sig af sin sygdom endnu, svag var han, og han erkendte for sin svagheds skyld at bruge for en skilling brændevin hver morgen "... og vilde forhaabe, at ingen hannem nogen overflødighed enten med brændevin eller tobak at bruge skal overbevise, lovende ogsaa herefter under sit kalds fortabelse uden videre paamindelse og foregaaende dom endelig og aldeles al brændevin og tobak drikken sig at entholde ....«. Forpligtelsen er indført i protokollen, og dell angrende synder har egenhændigt underskrevet den. ${ }^{93}$ ) Om det saa hjalp, er det ikke let at sige noget om. I hvert fald kom landemodet ikke mere til at beskæftige sig med Hr. Peters morgenlige styrkedrikke. Senere fik han iøvrigt kapellan.$^{94}$ ) Forhaabentlig er det ikke afholdenheden, der helt har slaaet ham ud.

De Spandet præster synes at have været lidt for sig selv. Om en af Peter Johansens forgængere, der ogsaa bar navnet Peter, fortælles det, at han paa 12 skridts afstand skal "have skudt med en flitsbue saa vis, at han aldrig fejlede ${ }^{95}$ ) $\mathrm{Og}$ Jens Petersen Møller, der 1660 blev præst i Spandet, ${ }^{90}$ ) fortælles der endnu meget mere og meget værre om. Han havde først været præst i Ensted sogn. Men det gik ikke saa godt. I 1642 blev han afsat, og grunden var, at han drak for meget og ikke

63) Landemodeprotokollen 89.

94) Arends: anf. sted I 288.

95) Rhode: Samlinger til Haderslev Amts Beskrivelse 508.

$\left.{ }^{96}\right)$ Den 20. juni 1660 meddelte biskoppen provsten, at sognefolkene i Spandet overløber ham om at faa Jens Møller til præst. Han har allerede erhvervet præsentatsbrev af amtmandens fuldmægtig (Kragelund Kopibog 122). Den 2 . novbr. blev han i Ribe paamindet om ikke at befatte sig med kirketjenesten i Spandet sogn, før han havde faaet kollats fra lensmanden og derpaa konfirmation af biskoppen i Ribe (Landemodeprotokollen 180). Den 19. december 1660 konfirmeredes hans kaldsbrev (Kragelunds Kopibog 125). 
paa tilbørlig vis overholdt det sjette bud. ${ }^{87}$ ) Efter at være afsat, blev han degn i Bedsted. Som saadan kaldtes han stadig Hr. Jens og skal have faaet lov til at beholde sin præstekjole.98) Iovrigt oplyser biskoppen i Ribe ved forhandlingerne om hans kaldelse i 1660 , at han havde faaet hertugens "restitution" for sin forseelse. ${ }^{99}$ ) Om hans senere skæbne fortæller en af hans efterfølgere paa Ensted prædikestol, Marcus Kjær (1848-1857), folgende: sognemændene i Spandet kendte ham som en munter og lystig mand og onskede derfor at faa ham til præst. Paa deres opfordring søgte han kaldet. Han fik det, men maatte love biskoppen, "at han aldrig mere vilde gaa i kroen«. Bønderne savnede ham imidlertid her. Men sit lofte kunde han jo ikke bryde. Bønderne var dog ikke jyder for ingenting. Raad manglede de ikke, og lune havde de. Paa hans vægring svarede de ham: "Saa kunde vi jo bære jer derhen!« - "Det gaar an!« svarede præsten, thi nu gik han ikke i kroen. Ordsproget: "Det gaar an, sagde Spandet præst, da bar de ham i kroen" stammer herfra. ${ }^{100}$ ) Omkring 1786 siges det at være i alle danskes munde. ${ }^{101}$ ) Hvormeget sandt der er i historien, lader sig vel ikke mere efterprøve. Men gammel er den i hvert fald. Allerede 1724 fortæller Bedsted præsten i sin kirkebog, da en ung mand var død: "Samme person havde til oldefader Hr. Jens Spandet, præst, som sagde: Det gaar an, da de bar ham i kroen .... «.

Naar man tager Jens Møllers tidligere meriter i betragtning, kunde man have ventet at se ham som en flittig gæst hos biskoppen i Ribe. I de fire aar efter 1660, hvorfra landemode-

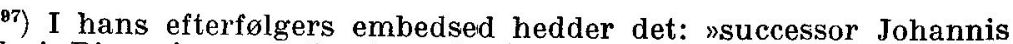
Molleri Ripensis, remoti adulteri« (O. H. Moller: Beitrag zur Kirchen- und Prediger Geschichten der Aemter Apenrade, Hadersleben etc. 5).

$\left.{ }^{88}\right)$ Bedsted Præstearkiv: 1754 „Geographisk-historisk Beskrivelse over Bedsted og tilliggende Sognebyer;; C. c. 3 (1569)-1807 Fldre Papirer angaaende Kirkens og de kirkelige Embeders Indtægter.

$\left.{ }^{89}\right)$ Kragelunds Kopibog 122 .

$\left.{ }^{100}\right)$ Ensted Præstearkiv: H. 8. ca. 1707-1874 Forskelligt. 1.

10) Rhode: anf. sted 508. Historien fortælles her iøvrigt om Jens Mallers forgænger Frederik Knudsen, der var præst i Spandet $1616-1630$. 
protokolllen er bevaret, staar han kun anklaget een gang. Det var i 1663, og selvom sagen ikke angik drik eller hor, var den alvorlig nok. Han beskyldtes "... for allehaande punkter udi sine prædikener, som synes farlige og den menige mand udi hans menighed til forargelse, som han efter ordinansen burde at sættes til rette for .... . Men han nægtede at have sagt dem paa den maade, ".... som de udtydes, som han og nogle af de første haver forklaret .... . Man kunde imidlertid ikke overbevise ham, og han synes ogsaa at være blevet støttet aî sin menighed, hvis vidnesbyrd han kunde fremlægge. Under disse omstændigheder blev han forskaanet og slap med en paamindelse om $" . .$. at have sine prædikener udi god agt og tale varligen baade om det højærværdige sakramente og det hellige kors' betegnelse, tilhørernes salighed og 'salighedens middel og sligt mere og lempe sig efter deres forstand og administrere sakramentet paa dansk, som det sig bør .... ${ }^{102}$ ) Hans letsindige udtalelser har vel mere været flotte bemærkninger end kætterske meninger. Letsindig har han været, hans liv viser det fra forst til sidst.

En anden præst, der ogsaa var lidt mere letsindig end flertallet af sine kollegaer, var Anders Pedersen i Rødding. Han havde engang været beskyldt for lejermaal. I 1656 havde han strid med ridefogden Laurids Pedersen. Han havde ladet falde et hastigt og ubetænksomt ord om denne. Nu maatte han tilbagekalde det. Han havde intet at beskylde ridefogden for paa hans gode navn og rygte til hans æeres forklejnelse, og det var heller ikke i den mening, at ordene var blevet sagt. Da amtmandẹn Cai Ahlefel,dt havde været tilstede, da de mindre pæne ord blev sagt, skulde han ogsaa have en undskyldning. ${ }^{103}$ )

Af nordslesvigiske præster $\mathrm{i}$ denne periode var det dog vist Søren Pedersen Hegelund i Skærbæk, som havde det voldsomste sind og den dristigste tunge. Hans udtryk kan minde ikke saa lidt om de første reformatorers kraftfulde renaissancesprog.

102) Landemodeprotokollen 222.

${ }^{103)}$ Landemodeprotokollen $137 \mathrm{f}$. 
I hvert fald blev han i 1643 beskyldt for at have brugt udtryk som æretyve, gudsbespottere, øretudere og skændegæster om nogle af sine sognebørn, med hvem han var kommet i strid. $O g$ en af dem, Anna Spandet, skulde han have frataget biskoppens stævning, slaaet hendes og sagt, at hun var fordømt, og dristelig svoret, at han havde fordømt hende. ${ }^{104}$ )

Den kristne kirke har altid lagt stærk vægt paa sine gejstliges sædelige vandel. Seksuel afholdenhed var den absolutte fordring til katolicismens præster og klosterbeboere. Men menneskene er mennesker, selvom de bærer præstekjole ell,er munkekutte, og det er en kendt sag, at et betydeligt antal af de katolske præster ikke evnede at holde deres løfter paa dette omraade. Selv efter at præsteægteskabet ved reformationen blev tilladt, forekommer det, at præster gjorde sig skyldige $\mathbf{j}$ brud paa de almindelige moralske læreregler. Og straffen herfor var naturligvis tab af embede. Men ofte fik naade gaa for ret. Karakteristisk er saaledes et tilfælde fra 1636. Anker Jensen, præst i Ballum, var beskyldt for at have besovet en kvinde. Sagen var drevet saa vidt, at han var dømt til at lovværge sig for den sag. Det kunde han ikke, selvom han paastod at være uskyldig. Kongen gav den 1 . december 1636 tilladelse til, at han ikke skulde tiltales videre for denne sag. Han skulde straks fratræde Ballum sognekald, men fik lov til at blive kaldet til et hvilket som helst andet embede i Danmark. ${ }^{105}$ ) I 1647 blev Anders Pedersen i Rødding stævnet efter Haderslev amtmandens befaling. En kivinde havde ved sit barns daab i Hammelev kirke tredie juledag 1646 udlagt ham som barnefader. Han benægtede det blankt, han havde aldrig ukyskeligen haft omgang med kvinden. ${ }^{106}$ ) Udfaldet af sagen

$\left.{ }^{104}\right)$ Landemodeprotokollen 79 f.; jvnfr. Sønderjydsk Maanedsskrift 1936. $110 \mathrm{f}$, hvor der er redegjort for en injuriesag, som ridefoged Hans Outzen i 1663 anlagde mod Hr. Søren. Bispen udtalte i den anledning, at nu maatte det være slut med hans evige trætter og stridigheder, som øvrigheden i saa mange aar havde fundet sig i (Kragelunds Kopibog 168 f., 175).

$\left.{ }^{105}\right)$ H. F. Rørdam: Danske Kirkelove III $258 \mathrm{f}$.

${ }^{106)}$ Landemodeprotokollen $89 \mathrm{f}$. 
kendes ikke, men afskediget blev den anklagede i hvert fald ikke. Ti aar før havde Rødding præstens kollega, den oftere omtalte Søren Hegelund, paa lignende maade staaet anklaget for lejermaal med Else Brodersdatter, der havde været amme hos ham. Præsten synes en tid at have været suspenderet, men fik dog lov til. foreløbig at fortsætte ».... eftersom menigheden i denne vinter ikke vel kan med tjeneste opholdes .... Sagen beh'andledes gang paa gang af landemodet, men til sidst lod man den falde, antagelig fordi det blev oplyst, at ammen var blevet paavirket af kapellanen Jacob Hansen, med bvem Søren Hegelund - som med næsten alle sine kapellaner - levede $\mathrm{i}$ det daarligst tænkelige forhold. ${ }^{107}$ ) I 1662 blev Niels Hjortlund i Mjolden suspenderet, fordi han havde besovet sin fæstemø. Men kaldet beholdt han i hvert fald, og det samme gælder præsten i Hygum, hvis kone i 1636 nedkom ti uger for tidligt; der var nok udstedt vidnesbyrd om, at barnet var ufuldbaarent, men disse var ikke udstedt af de kvinder, som havde synet barnet, men af deres mænd, og de var ikke taget til tinge. ${ }^{108}$ )

\section{Kirkernes økonomiske forhold:}

Kirkerne havde forskellige indtægtskilder, næsten alle af middelalderlig oprindelse. Kirkens økonomiske forhold varetoges af kirkeværgerne. Efter en instruks fra 1609, udstedt af ærkedegnen og Johanns Faust, skulde de indkræve kirkens iindtægter hvert aar før Mikkels dag og have dem parat i rede penge. Var der tale om større reparationsarbejder ved kirken eller andre udgifter, der oversteg fire eller seks mark, skulde de forst indhente ærkedegnens raad og samtykke, ${ }^{109}$ ) og dette forbud indskærpedes i 1653 ved en skrivelse til provsterne:

107) Landemodeprotokollen 19 ff.; 28 f.; jvnfr. Sønderjydsk Maanedsskrift 1936. $10 \%$.

$\left.{ }^{108}\right)$ Kragelunds Kopibog 76, 145.

$\left.{ }^{109}\right)$ Instruksen er indskrevet i en række bevarede kirkeregnskabsbøger fra Hviding herred (i præstearkiverne). 
uden biskoppens samtykke maatte de ikke befatte sig med bygning eller arbejde paa kirkerne. ${ }^{110}$ ) Indsættelsen af kirkeværger førte ogsaa engang til sammenstød mellem ærkedegnen i Ribe og amtmanden i Haderslev. I 1654 afviste biskop Kragelund $i$ et brev til kancellisekretæren Erik Kragh en klage over, at han skulde have fjernet kirkeværger, som amtmanden "for saa mange aar tilskikket." Der var $i$ hans tid to, som havde resigneret, begge 'var gamle udlevede mænd, hvoraf den ene endog lod kirken forfalde. Iøvrigt: efter Kolding recessen er det ærkedegnen, der hører regnskaberne, og amtsskriveren er kun bisidder paa amtmandens vegne. Der meldes intet om, at amtmanden har ret til at indsætte kirkeværger, og biskoppen afviser paa det bestemteste, at han skulde have en saadan ret. ${ }^{111}$ )

Naar regnskaberne skulde høres, fik kirkeværgerne paabud om at give møde med regnskaberne og pengene. Som regel blev alle kirkeværgerne $i$ et herred tilsagt til at møde $i$ en af herredets kirker. ${ }^{112}$ )

Langt den vigtigste af kirkens indtægter var tienden. Tiendeforholdene var meget forskellige $i$ kongerjget og $i$ de vestslesvigske sogne. I Tørninglen var korntienden ligesom i kongeriget delt i tre dele: præste-, kirke- og kongetiende, mens reglen i Sønderjylland - saaledes ogsaa i det gottorpske Vestslesvig - ellers var den, at der kun blev ydet en femtendedels tiende, saaledes at præsten og kirken hver fik halvdelen. ${ }^{113}$ ) Ogsaa i Tørninglen blev der kun tiendet med en femtendedel, hvoraf præsten fik halvdelen, mens kongen og kirken

110) Kragelunds Kopibog $17 \mathrm{f}$.

111) Kragelunds Kopibog 57.

112) Kragelunds Kopibog 37, 62.

113) Paa Erø gjaldt særlige regler. Der opkrævedes tienden med en tyvendedel og deltes mellem præst og kirke (Neue Staatsb. Magazin IX 173). Ogsaa paa Als deltes tienden i to dele, saaledes at kongen ingen tiende fik. Det hedder $i$ en bestemmelse fra 1621 om tienden paa Als: ".... skulde bønderne til kirke og præst tiende den tyvende kærv, men i hvilke sogne den 15. kærv bevislig eller brugelig er, der skulde de og tiende den 15. kærv, som er i Ketting og Tuntoft (d. v. s. Nordborg) sogn ...... Angaaende Oksbøl var der strid (kopi i Nordborg Præstearkiv). 
delte resten. De ikke kongelige fæstere, hvad enten de nu hørte under Gram, Schackenborg eller Lindeved, betalte den herskabelige del, altsaa $1 / 4$, til godsherren. Grunden til dette ejendommelige forhold var, at biskopstienden, der i kongeriget ved reformationen var blevet inddraget under kronen og forandret til kongetiende, i Sønderjylland var blevet ophævet kort efter maj 1525. ${ }^{14}$ ) Kirkens 30del blev dog i Haderslev amt delt mellem kirken og kronen. I Tørninglen blev dette forhold ved at bestaa, mens kongens andel $i$ tienden i Haderslev provsti, bortset fra en mindre afgift, ${ }^{115}$ ) paa et eller andet tidspunkt blev givet tilbage til kirkerne. ${ }^{116}$ ) Kongetienden blev ligesom i kongeriget som regel bortfæstet. I 1648 fik fiskemester og ridefoged Hans Bartram koncession paa kongetienden af de tørninglenske kirker. Ofte fæstedes den af bønderne selv. 1615 havde fire mænd i Skærbæk sogn dette sogns kongetiende i farste. ${ }^{117}$ )

I enklavesognene var forholdene ikke helt klare. Paa forlıaand skulde man mene, at der her herskede de samme forhold som i kongeriget. Der kan heller ingen tvivl være om, at der har været ydet kongetiende af disse sogne. Kronens tiende af Møgeltønder, Daler og Ballum sogne nævnes udtrykkelig i $1647 / 48,{ }^{118}$ ) og den sidste blev skødet til grev Schack i 1661. ${ }^{119}$ ) Kongetienden af kirkerne i Lø herred er maaske gaaet over til Trøjborg. Om der ogsaa i enklavesognene har været tiendet med en tiendedel, er ikke helt klart. 1558-1561 var der

114) Kirkehistoriske Samlinger 4. r. I 588; Jørgen Boetius' beretning j Nye kirkehistoriske Samlinger II 276 .

${ }_{115}$ ) Angaaende den i 1649 og 1652 paalagte afgift paa $1 \frac{1}{2}$ skilling lybsk af hver trave af konge- og kirketienden se: Haderslev Katedralskoles Arkiv: 1584-1790 Eldre Sager og Achelis: Haderslev i gamle Dage II 172. Angaaende den saakaldte straatiende, hvis oprindelser meget uklar: Haderslev Amtsarkiv: Kirkevisitatorialsager til den slesv. Registratur Nr. 1; Jahrbücher für die Landeskunde IV 73.

116) Neue Staatsb. Magazin I 330; Jahrbücher für die Landeskunde IV 73; Kirke-Kalender for Slesvig Stift 1862. 155; Haderslev Lensregnskaber (Ra.).

117) Acta A. XVII. 802 (Ra.); Haderslev Lensregnskaber 1615 (Ra.).

118) Riberhus Lensregnskab 1647/1648 (Ra.).

119) Kronens Skøder II 110. 
strid mellem præsten og sognefolkene i Møgeltønder angaaende tienden. To kongebreve befalede bønderne, at de $\mathrm{i}$ tiende skulde give hver tiende kærv, og siden skulde tienden deles mellem præst, kirke og kronen. Bønderne klagede over denne bestemmelse, og lensmanden skrev til kongen angaaende sagen. Han hævdede, at der ikke tidliger var blevet givet saadan tiende og heller ikke blev givet det af de omliggende sogne. Han bad om, at de for fremtiden maatte give det samme, som de havde givet $i$ gamle dage. ${ }^{120}$ )

Som det vil ses, var tiendeforholdene i Vestslesvig temmelig forskelligartede og indviklede. Bedre blev det ikke ved, at der fandtes ikke saa faa undtagelser fra de almindelige regler. 'Til Løgumkloster amtsstue betaltes der saaledes tiende af byerne i birket (Nørre-Løgum og Løgumkloster sogne samt Alslev og Vesterhøjst i Højst sogn) samt af Bodsholm i Højst sogn og af Kummerlev, Svanstrup og Trælborg i Brede sogn (før 1639 afløst med penge). ${ }^{121}$ ) Da der i Nørre-Løgum sogn, der dengang ogsaa omfattede Løgumkloster, ingen tiende betaltes til kirken, og præsten kun fik tiende af Ellum by og to gaarde i Løjtved, maatte begge have hjælp fra Brede kirke, der var meget velhavende, samt fra amtsstuen i Løgumkloster. ${ }^{122}$ ) Disse forhold skyldes, at klostret havde ejet kirkerne i Nørre-Løgum og Brede og dermed tienderne, ${ }^{123}$ ) som da er blevet erlagt paa klostret, efter sækulariseringen paa amtsstuen. Efterhaanden er tiendeafgifterne antagelig gledet sammen med de øvrige afgifter, som bønderne skulde betale. Mens erhvervelsen af tienderne af Brede og Nørre-Løgum sogne allerede var sket i det 12. eller 13. aarhundrede, var forholdet mellem Løgumkloster og byerne Alslev og Vesterhøjst først blevet ordnet paa reformationstiden. Abbeden i Løgumkloster hævdede, at Løgum kirke fra arilds

120) Tyske Kancelli. I. A. - 1670 X. "Die geistliche Jurisdiction .... (Ra.).

121) Løgumkloster Amtsregnskab 1639 og 1644/1645 (Ra.).

122) Acta C. V. 2. 182 og 3. 239; Acta A. VI. 74, Nr. 16;8\%, B. 1. i. Afgiften fra Brede kirke ophævedes først ved kongelig reskript af 30. juli 1819 (Aabenraa Provstearkiv: Brede).

${ }_{123}$ ) Scriptores Rerum Danicarum VIII 15 f, $113 \mathrm{ff}$. 
tid var de to byers rette sognekirke, saa meget desto mere som byerne laa i Lo herred og Ribe stift, der gik til Arnaaen, mens Højst hørte til Slesvig stift og Slogs herred. Klostret erhvervede flere breve angaaende dette forhold, udstedt af biskop, hertug og kongen. Men i 1529 gik abbeden dog $» . .$. for Guds skyld og for velbyrdige miænds skyld, som er mester Clawes Görtssen, Mattis Gördtssen og andre dannemænds bøns skyld .... med til, at de to byer skulde høre til Højst kirke. Til gengæld skulde klostret have halvdelen af al tienden af de to byer og af Bodsholm, mens præsten og kirken skulde dele den anden halvdel. ${ }^{124}$ )

I Abild sogn var tiendeforholdene særligt indvịlede, hvis man da kan tro præsten, der i 1648 skriver, at nogle giver en tyvendedel, nogle en enogtyvendedel, ja nogle maaske en tredivtedel, som saa skal deles mellem præst og kirke. Men de delte ikke lige: præsten fik ${ }^{2 / 3}$ og kirken 1/3. Saadan havde det været fra gammel tid. Der førtes en lang strid mellem sognemændene og præsten Matthias Friis, Ved en kontrakt af 10. juni 1648 lykkedes det at komme til enighed om en del stridspunkter. Sognemændene gik ind paa præstens onske om, at tienden, ligesom $i$ andre sogne, blev delt saaledes, at præsten fik hele tienden af visse byer, kirken af andre. I Abild skulde præsten have de ${ }^{2 / 3}$ af tienden, det blev altsaa 14 af sognets 21 bol. Det skulde staa ham frit for at tage tienden paa marken eller modtage den af sognemændene. Præsten havde gjort krav paa, at der ligesom i de omliggende sogne skulde ydes en femtedels tiende, men han fik kun en tyvendedel af de byer, hvis tiende skulde tilfalde ham. Til gengæld gav hans Sognebørn ham forskellige okonomiske indrømmelser. ${ }^{125}$ )

I Sønderjylland var det allerede i det 16. aarhundrede almindeligt, at der ikke blev tiendet i karven, men i skæppen, i rent korn efter en fast overenskomst. En saadan aflasning

124) Scriptores Rerum Danicarum VIII 29 ff; Tønder Provstearkiv: Højst: "Zum Kircheninventar.... ".

${ }^{125}$ ) Acta A. XX. 2531 (Ra.). 
var absolut den mest praktiske for tiendeyderen, men maaske næppe saa fordelagtigt for tiendenyderen. Bortset fra det rent praktiske ved denne ordning havde den .ogsaa den fordel for tiendeyderne, at de derved beholdt straaet af tienden, hvilket havde stor gødningsmæssig betydning. I 1709 fortæller sognepræsten i Rødding, at bønderne fører tienden til præstegaarden i rent korn, ".... naar han føjer samme i deres begæring, at de kan beholde deres straafoder selv .... ${ }^{126}$ ) Lignende betragtninger fremføres gang paa gang af tiendeyderne, da tiendeafløsningen $i$ det 18. aarhundrede blev aktuel i kongeriget.

Øvrigheden tog som regel stilling imod afløsningen, som den flere gange udtrykkelig forbød. Den 27. december 1575 udstedte hertug Hans saaledes en forordning om, at saavel kirke- som præstetiende skulde erlægges i kærven. Præsterne og kirkeværgerne skulde selv drage rundt og udtage tiendekornet, ${ }^{127}$ ) og nogle faa aar efter udgik der et kongeligt brev om, at sognemændene i Ballum sogn skulde yde deres tiende i kærven, ikke i skæppen. ${ }^{128}$ )

Men trods de forskellige forbud, blev der indgaaet tiendeoverenskomster. I 1583 enedes man i Emmerlev om, at kirketienden for fremtiden skulde leveres i rent korn. Blev afgiften ikke betalt i rette tid, havde kirkeværgerne ret til at pante derfor. I 1615 klagedes der over, at ærkedegnen i Ribe i modsætning til, hvad der var gammel skik og brug, tvang indbyggerne j Emmerlev til at tiende paa marken. ${ }^{129}$ ) En lignende overenskomst som i Emmerlev fandtes med hensyn til præstetienden $\mathbf{i}$ Højer sogn allerede $\mathrm{i}$ det 16 . aarhundrede. ${ }^{\mathbf{1 3}^{0}}$ ) I Brede sogn indgik amtmanden i Logumkloster Siwert v. d. Wisch og sogne-

126) Haderslev Amtsarkiv: Forarbejder til Jordebogen $1706 \mathrm{ff}$.

127) Rhode: Samlinger til Haderslev Amts Beskrivelse $13 \mathrm{f}$; junfr. hertug Hans' brev af 4. august 1578 (Topografica: Haderslev (14341748) "Copiale von Priv. und Verordn. pp .... 65 ff.). $15 / 3$.

${ }^{128}$ ) Corpus Constitutionum II 127; Kancelliets Brevbøger 1579

${ }^{129}$ ) Acta XX. 2539 (Ra.).

$\left.{ }^{130}\right)$ Rolfs: Geschichte des Kirchspiels und Fleckens Hoyer $89 \mathrm{f}$. 
folkene den 16. oktober 1594 overenskomst om, at i stedet for som hidtil at betale tienden "in garuen", skulde der herefter betales 44 ortug korn, halvt rug, halvt byg. Denne afgift blev dog ogsaa afløst, idet det fastsattes, at der for hver ørtug korn skulde betales tre mark og fire skilling. Overenskomsten var til evige tider uopsigelig fra begge sider. ${ }^{131}$ ) I Højst havde præsten ogsaa været nødt til at enes med beboerne om en afgift i rent kcrn; men da han i 1639 beklagede sig derover, bestemte amtmanden, at tienden skulde leveres in natura. Præsten kunde ikke være bundet af de aftaler, som forgængeren havde truffet med sognefolkene. Naar der i den følgende tid blev truffet aftale om afløsning, gjaldt overenskomsten kun i et aar. I 1675 eriedes man dog atter om en nyordning: præsten skulde herefter have 75 tonder rent korn. ${ }^{132}$ )

Ofte var tienden afl,øst paa den maade, at der betaltes en bestemt afgift af hver gaard eller hver otting. I Visby sogn saaledes omkring 1650: 10 skæpper byg og to skæpper rug $i$ godt ydefærdigt rent korn af hver gaard. ${ }^{133}$ ) En tilsvarende ordning fandtes ogsaa i Ballum sogn 1649 for præstens vedkommende og senere i Skast for kirkens vedkommende. ${ }^{134}$ ) Selvom der ikke var truffet nogen bestemt overenskomst, var det dog ret almindeligt, at kirketienden for nogle aar bortfæstedes til sognefolkene eller til enkelte af dem. ${ }^{135}$ ) Der kunde naturligvis ogsaa godt kun træffes overenskomst med tiendeyderne i en enkelt af sognets byer. I 1636 saaledes med bymændene i Vesterbæk, Roager sogn. ${ }^{138}$ )

Iøvrigt var forholdene skiftende fra sogn til sogn, fra egn til egn. I det store og hele synes det, som om afløsningen var

131) Ribe Bispearkiv: Archidiakonatets Kirkeregnskaber for Lø med flere Herreder $1554-1660$.

132) Tønder Provstearkiv: Højst: „Zum Kircheninventar ......

$\left.{ }^{133}\right)$ Regnskabsbog for Visby Kirke 1649-1773.

134) Sønderjydske Aarbøger 1930. 63; Skast Præstearkiv: C. c. 1. 1738-1773 Kirkeinventarier.

$\left.{ }^{135}\right)$ Se for eks. for Mjoldens vedkommende: Kragelunds Kopibog 47.

138) Ribe Bispearkiv: Chr. Bordings Kirkeregjster 1639 (V.). Senere opstod der en stor strid om denne kontrakt (Ribe Bespearkiv: Hviding Herred Ad. Reg. Nr. 7, Capsa 16, Pk. 1). 
almindeligere, desto længere man kommer mod syd, og hyppigere fandt sted for kirkernes end for præsternes vedkommende. I Lø herreds seks sogne var præstetienden i 1649 kun afløst i Ballum og Visby sogne, mens Kirketienden omkring 1650 i hvert fald var afløst eller bortforpagtet i fem af de seks kirker. ${ }^{137}$ )

Af kirkens øvrige almindelige indtægter kan nævnes de saakaldte kopenge, i registrene ofte betegnet med hura vaccarum. Det var afgifter af evige køer eller jernkøer. Disse var, som regel i den katolske tid, blevet skænket til kirken som sjælegave. Da kirkeværgerne ikke kunde passe en større besætning, blev de sat ud til bønderne, som betalte en afgift af dem. Men afgiften varede ikke blot saa længe, koen levede, men til evindelig tid. Koen kunde ikke dø. Ved en skrivelse af 31. marts 1679 fastslog amtmanden i Haderslev udtrykkeligt, at selvom en mand overtog en øde gaard uden besætning, skulde han betale den koafgift, der hvilede paa gaarden. ${ }^{138}$ ) Antallet af køer var selvfølgelig varierende fra sogn til sogn, for eksempel: ${ }^{138}$ )

$\begin{array}{lrlrlr}\text { Vodder: } & 19 & \text { Gram: } & 9 & \text { Skærbæk: } & \mathbf{6} \\ \text { Rejsby: } & \mathbf{1 5} & \text { Randerup: } & 15 & \text { Spandet: } & 10 \\ \text { Hviding: } & 15 & \text { Døstrup: } & 19 & \text { Toftlund: } & 29 \\ \text { Arrild: } & \mathbf{3 1} & \text { Mjolden: } & \mathbf{1 3} & \text { Rømø: } & \mathbf{4 4} \\ \text { Agerskov: } & \mathbf{4 8} & \text { Visby: } & 30 & \text { Bevtoft: } & 38 \\ \text { Tislund: } & 22 & \text { Brede: } & 32 & \text { Nustrup: } & \mathbf{4 2} \\ \text { Branderup: } & \mathbf{2 4} & \text { Brøns: } & \mathbf{5} & \text { Skrydstrup: } & 17\end{array}$

Afgiften var $i$ de her nævnte tilfælde enten $1^{1 / 2}$ eller to skilling.

$\left.{ }^{137}\right)$ Sønderjydske Aarbøger 1930. 63 ff. I Lundtofte herred var kirketienden som regel ogsaa aflost (Neue Staatsb. Magazin II 875). I Als sønder herred, hvortil Kegnæs den gang ikke hørte, blev i 1690 saa at sige al præste- og kirketiende ydet i korn (Acta A. VI. 209 (Biskoppen over Als og Ærø).

${ }^{138}$ ) Top. Haderslev Amt: 1434-1748) „Copiale von Priv. und Verordnungen p. p. .... 313 .

138) Ribe Bispearkiv: Chr. Bordings Kirkeregister 1639 (V.) samt Kirkeregnskabsbøgerne; jvnfr. Sønderjydske Aarbøger 1930. $226 \mathrm{ff}$. 
Foruden køer var det ogsaa i. middelalderen almindeligt, at fromme folk eller folk med en lidt sort samvittighed skænkede kirken enkelte agre eller tofter. Paa denne maade er det meste af den jord, der benævnes kirkestuf, blevet til. Kirken lejede jorden ud mod en vis afgift. Det meste af denne jord blev reddet igennem de vanskelige aar under reformationen, men paa grund af pengenes synkende værdi, blev afgifterne j tidens løb mindre og mindre værd, og i det 17 . aarhundrede drejede det sig ikke om ret store beløb, tit kun nogle faa mark. Bedst stillet var kirken i de tilfælde, hvor afgiften erlagdes $i$ korn. I nogle sogne havde kirken ogsaa en eller flere gaarde, som selvfølgelig ogsaa maatte bortfæstes.

En indtægtskilde, der undertiden kunde være ret betydelig, var rentepengene af kapitaler, udlaant til private eller til andre kirker. Det kunde ofte dreje sig om ret store beløb. I 1631 havde Agèrskov 2137 mark lybsk, Roager 925 mark lybsk og 1 skilling, Brøns 1156 mark lybsk, Skærbæk 1182 mark lybsk og 8 skilling, Arrild 1029 mark lybsk, 5 skilling og 6 d. paa rente. Var hus eller gaard sat til "visse og forvaring" for kirkens penge, var salg eller bortpantning forbudt. Blev renterne ikke hetalt til rette tid $" . .$. paa skammel, naar regnskab gøres.... da skal straks med lovmaal forfølges og udgive hovedstol og rente og have forbrudt 18 skilling til fyrstelig naade og 18 skilling til kirken.... ${ }^{10}{ }^{100}$ ) Som oftest var disse kapitaler erhvervet ved opsparing, 'men tit stammede de fra gaver. Ogsaa efter reformationen forekom det ret hyppigt, at fromme sognefolk betænke kirken eller de kirkelige institutioner. I Ubjærg havde Bendix Petersen saaledes foræret kirken 88 mark lybsk, og omkring 1590 skænkede Jens Petersen den ældre 100 mark til kirken, "... dass ein Karn Haus vor der Norder Thür dafür sollte gebawet werden.... «. Men døren blev muret til, og pengene sat paa rente. Hemme Fridrichsen i Sæd forærede i 1652 kirken 50 mark, hvoraf renten skulde bruges til at betale

140) Acta A. XVII. 802 (Ra.); Top. Haderslev Amt: (1434-1748) "Copiale von Priv. und Verordnungen p. p.... $68 \mathrm{ff}$. 
skolepenge for fattige born i sognet. Naar adelige eller de velstaaende bønder købte begravelser i kirken, maatte de betale godt derfor. Omkring 1650 gav Marrin Fridrichs saaledes 50 mark til Ubjærg kirke for en begravelse. Hver gang den blev aabnet, skulde der betales tre mark. ${ }^{141}$ ) $\mathrm{Og}$ en del aar senere betaltes der 50 mark til Brede kirke for en begravelse i kirken til forvalterfruen paa Trøjborg. ${ }^{142}$ )

Kírkernes Udgifter var meget mere mangeartede og forskellige end deres indtægter. Visse poster gik igen fra aar til aar. Som eksempel kan tages Brøns kirkes ordinære udgifter for aaret 1654:

Provsten: 6 mark tjeneren: 8 skilling skriveren: 3 mark. studenterpenge: 3 mark præsten: 3 mark degnen: 3 mark studenterpenge for Vester-Vedsted kirke $\mathrm{i}$ to aar: 6 mark kirkens klæder at to: 2 mark de fattige: 3 mark skolemesteren: 3 mark til fortæring: 5 mark. ${ }^{143}$ )

Af andre udgifter, der var stadigt tilbagevendende, kan nævnes katedraticum, der indførtes ved kgl. brev af 23. juni 1683, og var en afgift paa en rigsdaler af alle kirker, hvad enten de var .... under jure patronatus heller ej, med mindre det af skødene kan bevises, at de for slig cathedratico at udgive er fri og forskaanede.... ${ }^{144}$ ) Desuden penge til voklys og til vin og brød, forsaavidt der ikke var henlagt særlige indtægter hertil.

Af de uvisse udgifter gik langt de fleste selvfølgelig til kirkens reparation og vedligeholdelse. Kirkeregnskaberne indeholder derfor værdifulde bidrag, ikke blot til kirkernes bygningshistorie, men ogsaa til datidens handelshistorie. Man faar saaledes, for at tage et par eksempler, et stærkt indtryk af, i hvor høj grad sognene i Haderslev vesteramt betragtede Ribe

141) Ubjærg Præstearkiv: C. c. 1. 1581-1906 Kirkeinventarier og forskellige Efterretninger og Indberetninger. Angaaende legater til Højer kirke se Rolfs: anf. sted 31 f., 45.

${ }^{142}$ ) Trøjborg Godsarkiv: Pk. 8. Kirker og Skoler.

$\left.{ }^{143}\right)$ Ribe Bispearkiv: Archidiakonatets Kirkeregnskaber for Tørninglen 1625-1688; Regnskaber 1591-1654.

144) Top. Haderslev Amt: 1434-1748) "Copiale von Priv. und Verordnungen p. p....थ $294 \mathrm{f}$. 
som deres naturlige handelsforbindelse. En undtagelse danner dog tømmerhandelen, hvor Aabenraa er absolut dominerende. Denne by havde allerede $\mathrm{i}$ det 17 . aarhundrede meget stærk forbindelse ostpaa, især med Sverige, og hentede derfra en mængde tømmer, som saa - hvad ogsaa toldregnskaberne fra det 17. aarhundrede viser - videresolgtes til alle egne af Nordslesvig. Ja helt fra den vestlige del af Mellemslesvig kom der folk til Aabenraa, som købte tømmer med hjem. Interessant er det ogsaa at se, at der ofte hentedes tømmer til de tørninglenske kirker fra Farris. De store skove paa dette strøg, havde man endnu ikke faaet helt udryddet. ${ }^{145}$ )

Af andre ret hyppigt tilbagevendende udgifter kan nævnes: betaling for kirkens majning til pinsefesten, forrentning af eventuel gæld, øl til bymændene, naar kirkens regnskab blev hørt, eller tienden blev afleveret, saaledes for eksempel i Højer og Toftlund, Nustrup og Skærbæk. Herom udtalte ærkedegnen i 1620 , at bønderne har haft ret til "sogneøllet" fra arilds tid. Han mente, at det var bevilget for at faa bonderne til at tiende desto villigere. ${ }^{146}$ ) Nogle steder fik degnen ogsaa særlig betaling for at slaa bedeklokken. Mere enestaaende er udgifter til »... tṿende drenge, som løb om udi sognet og tilsagde folkene at møde til regnskab.... (Møgeltønder 162\%/28) eller fire skilling for at lade rydde møg og skarn ud af taarnet (Skarbæk 1640).

Tidens krige og den politiske og religiøse uro i Europa giver sig ofte udtryk i kirkeregnskabsbøgernes udgiftsposter. De fjendtlige tropper, som $i$ løbet af en 30 aar tre gange valtede op gennem Jylland, huserede og brandskattede, selvom disse egne næppe led saa stærkt som østkystens sogne, der laa lige ved den store hærvej. Mange præstegaarde gik under disse krige op i luer, og mangen en præstemand maatte flygte fra

$\left.{ }^{145}\right)$ Kirkeregnskaberne findes dels i præstearkiverne, dels i Ribe Bispearkiv og Tønder Provstearkiv.

$\left.{ }^{148}\right)$ Ribe Bispearkiv: Æredegn Æ̇gidius Laurentius: Regnskabsbog for Kirkerne i Lø Herred m. v. 1613-1620 (V.). 
hjem og kald, især til Ribe. ${ }^{147}$ ) I Hjerpsted kirkeregnskab opføres $1643 / 1644$ en udgift paa 12 mark "... til svenskens rytter for præstegaarden, som de vilde anstunget med ild...... Og tilsvarende bemærkninger møder man gang paa gang. I Møgeltønder klager præsten i 1649 over de ulemper, kejserkrigen og Torstenson fejden har medført. Begge gange havde der været stor indkvartering og beskatning til kvartermestre og andre officerer, ».... foruden daglig skansen her paa Møgeltønder slot og berøvelse med heste og kvæg, saa præsten ikke heller blev forglemt og forskaanet (besynderlig udi svenske tid) med trusel for beskatnings skyld formedelst brand eller afbrækken, som det gik denne slot udi "afftoggen« saavelsom andre fattige folk udi sognet.... to heste og maatte kontribuere til fyrstens prast eller pater raa Haderslevhus. ${ }^{148}$ )

En anden' følge af de mange europæiske krige - især trediveaarskrigen - var de talrige flygtninge, som, fordrevet fra hus og hjem, drog igennem landene, betlende sig fra sogn til sogn, som regel med kongeligt eller fyrsteligt brev. Snart gives der nogle skilling til en fattig præstedatter, fordrevet fra Lüneburg, snart til en fordrevet adelsmand fra Eisenach, en fordreven kvinde fra Østrig, en fattig student eller præst. Særlig godt betænktes konvertitterne. I Brøns fik en tysk mand, som havde givet sig fra den katolske til den luterske tro, i 1652 tre mark lybsk.

\section{Præsternes akonomiske forhold:}

Præsterne havde ligesaa lidt som de fleste andre af datidens embedsmænd fast løn. Deres indtægter var mangeartede og forskellige: Foruden korn- og kvægtiende havde de en del naturalydelser: smørbør, ost og brød. Endvidere offer og ac-

147) Carsten Petersen: Slesvigske Præster 336, 339, 342 f.; Sønderjydske Aarbøger 1933. 226 f.; Ribe Bispearkiv: Indkomne Breve 1569 -1685 (V.).

148) Møgeltønder Herredsbog 1649 (i Ribe Bispearkiv). 
cidenser. Til præstegaarden laa der som regel jord paa bymarken paa lignende maade som til en almindelig bondegaard. Endvidere havde præsten ofte fra katolsk tid bevaret en del enkelte jordstykker, som var givet til præstens bord: mensalgods. I mange af de nordslesvigske sogne var der efter svenskekrigene, da saa mange af landets gaarde laa øde hen uden dyrkere, blevet tillagt præsterne en ødegaard. I 1662 fik præsten i Brede saaledes en gaard i Apterp, som i fire aar havde været øde. Han skulde betale 10 rigsdaler deraf, men være fri for ægt og hoveri. ${ }^{149}$ ) En ekstra indtægt havde præsterne ofte af de kaadnere eller forbedelser, som havde bygget paa præstens jord. Foruden et mindre pengebeløb ydede de som regel ogsaa nogle dages arbejde til præsten.

I Brøns og Emmerlev sogne, der var henlagt til ærkedegnen i Ribe, var præsternes forhold ringere end i de ovrige sogne. Rent formelt var ærkedegnen nemlig sognepræst og den fungerende præst kun kapellan. Han maatte derfor yde en vis aarlig afgift til Ribe. I Brøns var det 24 Riber ørtug korn til ærkedegnen. ${ }^{150}$ ) I Emmerlev maatte præsterne indtil 1571 give to læster korn til ærkedegnen, men da Frederik den anden i 1571 skrev til ærkedegnen om at nedsætte afgiften, blev der oprettet en kontrakt mellem denne og præsten om, at der fremtidig skulde ydes en læst eller 24 Emmerlev ørtug. Senere prøvede ærkedegnen flere gange at komme uden om denne kontrakt. Den blev dog fornyet i 1598, men i 1637 gik præsten med til at forandre afgiften til 22 Riber ørtug, der skulde leveres i Ribe. Han var ikke rigtig klar over, hvad en Riber ørtug var, men opdagede snart, at forandringen ikke var til fordel for ham. Han havde desuden stor udgift til forsendelsen: skibsfragt og an-

149) Acta C. V. 154. Angaaende de særlige forhold i Abild, hvor præsten havde fæstet en af kronens gaarde se: Sønderjydsk Maanedsskrift 1937. 205 ff. og Acta A. XX. 2531 (Ra.).

150) Hviding Herreds Provstearkiv: »Prouste Bog udi Huidding Herret《 $\mathbf{1 6 4 9}$. 
det. $^{\cdot 51}$ ) I Ballum sogn var forholdet et lignende. Kirken var fra gammel tid annekteret tre af Ribe kapitlets medlemmer, og til disse maatte der betales 48 ortug korn. ${ }^{152}$ )

I en stor del af Vestslesvig ejedes præstegaardene i det 17. aarhundrede dels af kirken (eventuelt af menigheden), dels af præsten. Oprindelig havde de vist helt været ejet af kirkerne, men efterhaanden gik en del af deres bygninger over til at blive præsternes private ejendom. Dette skete ikke paa een gang, men gradvis. Grunden var, at præsterne tit ikke var tilfreds med de bygninger, der var. Paa egen bekostning byggede de til og udvidede. Men naar præsten døde, og hans efterfølger flyttede ind i præstegaarden, opstod problemet, hvordan man skulde forholde sig med de dele af præstegaarden, der var præstens private ejendom. Mange stridigheder kunde dette spørgsmaal give anledning til. Men det var dog efterhaanden alle steder en fastslaaet regel, at præsten eller hans arvinger skulde have godtgørelse for den del af præstegaarden, der var deres ejendom. Iøvrigt var forholdene ofte temmeligt indviklede. I Ubjærg underholdtes 18 fag af sognet. Til bygningen af et bagerhus paa fire fag gav sognet i 1676 en vis sum penge paa den betingelse, at præsten selv vedligeholdt bygningen, dog med undtagelse af skorsten, bagerovn og vandbrønd..$^{153}$ ) I Abild havde præsten repareret præstegaardens lade og stald. Hertugen bestemte $\mathrm{i}$ 1652, at der tilkom ham og hans arvinger erstatning derfor, og bygningen blev vurderet. I 1655 var præstens økonomiske forhold daarlige, blandt andet paa grund af børnenes studier. Han fik derfor hertugens brev paa, at kirken skulde erstatte ham hans udgifter og herefter vedligeholde

151) Emmerlev Præstearkiv: B. b. 1550-1804 Tingsvidner, Skrivelser m. m. angaaende Emmerlev Sognekald; Ribe Bispearkiv: Møgeltønder Herredsbog 1649; Sønderjydske Aarbøger 1911. 200. Om forskellen mellem Ribe skæppen og Møgeltønder (Emmerlev) skæppen se: Nordisk Kultur XXX 211.

${ }^{152}$ ) Sønderjydske Aarbøger 1930. 63.

153) Ubjærg Præstearkiv: C. c. 1. 1584-1906 Kirkeinventarier og forskellige Efterrretninger og Indberetninger. 
bygningerne. Sagen var dog ikke hermed afgjort. Sognefolkene vilde ikke betale. Tre aar senere fik amtmanden og provsten ordre til at kalde de stridende parter for sig og overtale præsten til at opgive sit krav, saaledes at efterfølgeren skulde godtgøre forbedringerne. ${ }^{154}$ )

I enklavesognene var forholdet endnu i det 17. aarhundredes sidste aar det samme som i de sogne, der hørte til Slesvig: stift. I 1690 underholdt Møgeltønder kirke saaledes 25 fag af præstegaarden og i Emmerlev 22 fag; i Daler ejedes og vedligeholdtes den af kirken og patronen "saavelsom andre steder i grevskabet«. Kun nogle fag lade, nogle huse og et studerekammer paa østersiden af dørnhuset, som var blevet opsat af en af de tidligere præster, var privat ejendom og maatte købes af den tiltrædende præst. Paa Rømø ejedes stuehuset af kirken. Omkring det 17. aarhundredes midte ejede og underholdt kirken 18 fag af Visby præstegaard, syv fag af Randerup, 12 fag af Mjolden og 18 fag af Døstrup præstegaard. ${ }^{155}$ ) I kongeriget var det siden 1661 i næsten alle tilfælde saaledes, at præsterne ejede præstegaarden. Præsterne i enklavesognene havde ogsaa været sammenkaldt $i$ anledning af en bestemmelse $i$ gejstlighedens privilegier, der fastslog, at præsterne skulde købe deres præstegaarde eller i hvert fald forrente købesummen. Biskoppen begærede dog ikke, at de skulde købe deres præstegaard, eller at de skulde udstede obligationer paa købesummen, da kirkerne havde ladet bygge og vedligeholde den største og bedste del af husene ".... efter den brug, som her i nabolaget i de holstenske kirker af arilds tid efter fyrstelige privilegier har været vedtaget $\ldots .{ }^{156}$ )

154) Abild Præstearkiv: B. d. 3. 1636-1879. Indkomne Sager vedr. Abild Præstekald; Acta A. XX. 2531 (Ra.); Sønderjydsk Maanedsskrift 1937. 208 f.

is5) Ribe Bispearkiv: Møgeltønder Herredsbog 1649 og Kirkeregnskaber for de paagældende sogne; Sønderjydske Aarbøger 1930. 85; Trøjborg Godsarkiv: Pk. 8. Kirker og Skoler.

156) Ussing: Kirkeforfatningen i de kongelige danske Stater III. 2. 672; Kragelunds Kopibog $198 \mathrm{f}$. 
Da alle kirkerne i enklavesognene var private, kunde patronen her faa indflydelse paa dette forhold. I Visby var ejeren af Trøjborg i 1653 utilfreds med, at præsten havde ladet kirken betale vedligeholdelsen af præstegaarden. I 1591 var der sluttet kontrakt mellem den daværende ejer og præsten om, at denne selv skulde vedligeholde præstegaarden, idet hans arvinger skulde have erstatning for, hvad han byggede paa den. Efter kejserkrigen bevilgede patronessen dog af sin gode vilje, at undersaatterne maatte hjælpe ham med at vedligeholde taget. Dette blev dog for meget for dem, og de beklagede sig. Der fandt saa en hovedreparation sted, hvorefter præsten selv skulde vedligeholde præstegaarden. ${ }^{157}$ )

Ogsaa paa disse egne blev der selvfølgelig ydet erstatning for præsternes private andel i præstegaarden. Den 5. april 1621 tinglystes saaledes paa Lø herredsting en kontrakt, mellem $\mathrm{Hr}$. Ogge Hansen, tidligere præst i Mjolden, og hans efterfølger Peder Andersen om, at for den bygning, som Hr. Ogge havde ladet bygge paa Mjolden præstegaard, og for al boskab skulde der betales 200 mark lybsk. Summen skulde dog kun udbetales, hvis Hr. Ogge absolut behøvede pengene, ellers skulde den blive staaende paa rente, saaledes at der betaltes 1 skilling lybsk i aarlig rente $\left(6^{1 / 4} \mathrm{pCt}\right.$.), saa længe $\mathrm{Hr}$. Ogge levede. $\left.{ }^{158}\right)$

I modsætning til, hvad tilfældet var i det gottorpske Vestslesvig og i enklavesognene, var forholdet i Tørninglen i det 17. aarhundrede $\mathrm{i}$ det store og hele det, at præsterne selv ejede og selv maatte underholde deres præstegaarde. Allerede i det 16. aarhundrede var dette tilfældet i Hviding herred. I 1569 udstedte hertug Hans en forordning, hvori det hedder, at i modsætning til, hvad der ellers var almindeligt i fyrstendømmet, maatte præsterne i Hviding herred selv vedligeholde deres præstegaarde, uden at deres arvinger efter deres død fik nogen godtgørelse. Det blev. nu fastslaaet, at de herefter skulde have godtgørelse for det, som de bevisligt havde bygget paa deres

157) Trøjborg Godsarkiv: Pk. \&. Kirker og Skoler.

158) La Herreds Tingbog. 
præstegaarde paa egen bekostning. Vurderingen skulde foretages af otte upartiske sognemænd. ${ }^{158}$ )

I Branderup overtog præsten Thomas Petersen i 1618 vedligeholdelsen af de 10 fag af præstegaarden, som sognemændene hidtil havde vedligeholdt. Til gengæld tilhørte de ham og hans arvinger. Da præstegaarden i Hjortlund brændte omkring 1649, byggede præsten den op paa egen bekostning ved medlidende venners hjælp. ${ }^{160}$ ) I Skrydstrup ejede præsten i 1655 alle præstegaardens huse og bygninger, som han havde købt og tilforhandlet sig. ${ }^{161}$ ) At forholdet $\mathrm{i}$ det 17. aarhundrede var det samme i de øvrige sogne i Tørninglen, fremgaar dels af kirkeregnskaberne, hvor det er en ren undtagelse af finde udgifter til vedligeholdelsen af præstegaardene, dels af den store jordebog for Haderslev amt, som blev udført i det 18. aarhunderedes første Aarti og hvor der udførligt redegøres for præstegaardenes bygninger og afløsningssummer. ${ }^{102}$ ) Undtagelser har der dog maaske været. Præstegaarden i Agerskov skal saaledes først i 1710 helt være blevet overdraget præsten. ${ }^{16: 3}$ )

Dette forhold, der iøvrigt var ganske det samme som i kongeriget, var afgjort ikke til fordel for præsterne. De unge, der tiltraadte deres forste embede, blev straks fra begyndelsen spændt haardt for, og senere kunde vedligeholdelsen blive en haard byrde for de ikke altfor godt aflagte sjælesørgere. Resultatet kunde let blive, at præstegaardene blev forfaldne og brøstfældige. Man har da ogsaa et enkelt eksempel paa, at en præst har forsøgt at faa spørgsmaalet taget op til debat. Det var Egidius Laugesen Wedel i Brøns. Han spurgte i Ribe, om det af kirkens bog fremgik, om præstegaardsbygningen tilhørte

\footnotetext{
159) Acta A. XVII. 802 (Ra.), trykt Aagaard; Beskrivelse over Tørning Lehn $246 \mathrm{f}$.

${ }^{100)}$ Grønlundske Papirer II 26 (Katedralskolen i Ribe); Ribe Bispearkiv: Kalvslund-Frøs Herredsbog 1649 (V.).

161) Ribe Bispearkiv: Ad Reg. Nr. 7, Capsa 11, Pk. 1.

182) Haderslev Amtsarkiv: Forarbejderne til Jordebogen 1706 ff; selve jordebogen findes i Rentekammerets arkiv i Rạ.

$\left.{ }^{163}\right)$ Aagaard: anf. sted 127.
} 
kirken eller præsten. Arkedegnen, biskop Kragelund, og kirkeskriveren, Hans Outzen, erklærede i 1670 under paaberaabelse af hertug Hans' forordning fra 1569, at præstegaardenes bygninger maatte tilhøre præsten og derfor skulde vedligeholdes af denne. $\left.{ }^{16 n}\right)$

Foruden køb af præstegaarden maatte den tiltrædende præst ogsaa ofte forpligte sig til - foruden afgiften i naadsensaaret - at give forgængerens enke aftægt af kaldet. Der blev saa som regel oprettet en kontrakt herom. Dette skete ogsaa i 1677 mellem sognepræsten paa Rømø Jens Engelbretsens enke Maren og den tiltrædende præst Søren Aagaard. Enken skulde i naadsensaaret have halvdelen af rugsæden og af al den visse indtægt, rettighedspenge, offer, smørbør og skipperlavspenge. Ved skipperlavet skulde hun dog udrede halvdelen af udgifterne. Hr. Søren skulde holde hende fri for alle udgifter iøvrigt. De huse, der tilhørte hende, skulde betales med rede penge efter uvildige mænds vurdering. Det sydligste hus blev det dog bevilget hende at flytte, hvorhen hun vilde. Hendes aarlige aftægt fastsattes til 20 rigsdaler, en tønde rug og enotting smør. ${ }^{165}$ )

. Iøvrigt opstod der ofte strid om indgaaede aftægtskontrakter. Et er at love. Et andet at holde. Naar præsterne nægtede at overholde de indgaaede kontrakter, maatte de naturligvis have en grund dertil. Det havde Jens Møller ogsaa, da han $i$ 1663 havde strid med forgængeren Hr. Krabbes enke. Han klagede over, at han i begyndelsen var blevet bedraget angaaende kaldets indtægt, som af hende var angivet højere end den i virkeligheden var. ${ }^{166}$ ) Ogsaa den stridens mand i Skærbæk, Søren Hegelund, havde disput med sin forgængers kone, Lene Iversdatter, som han havde lovet en aarlig afgift i korn, da han fik embedet, efter at forgængeren Johannes Andersen var ble-

\footnotetext{
164) Brøns Præstearkiv: B. b. Gamle Embedsskrivelser m. m. 1522-1782, Nr. 13.

165) Rømø Præstearkiv: (1628)-1846 Liber Daticus for Rømø.

$\left.{ }^{106}\right)$ Landemodeprotokollen $222 \mathrm{f}$.
} 
vet afsat, fordi han havde dræbt sin kollega, præsten i Brøns. ${ }^{167}$ ) Flere gange fik han breve fra lensmand og biskop om at overholde $\sin$ forpligtelse, og 1645 fik han at vide, at stillede han hende ikke tilfreds, vilde han blive stævnet. ${ }^{188}$ ) I 1649 indgik de en kontrakt om betaling af restancer, men endnu saa sent som i 1661 klagede Lene Iversdatter over, at han ikke holdt den indgaaede kontrakt. Amtmanden i Haderslev og biskoppen i Ribe fik ordre til at sørge for, at han betalte, hvad han var skyldig, saa man en gang for alle kunde blive fri for overlob i denne sag. Man forstaar egentlig godt, at man i København som vel ogsaa forlængst i Ribe - var ved at tabe taalmodigheden med den gode Hr. Søren i Skærbæk. ${ }^{169}$ ) Iøvrigt kunde det maaske virkelig knibe for den Skærbæk præst at udrede, hvad han havde lovet. Haardt var han spændt for. Over 1800 mark lybsk maatte han betale for præstegaarden, og endnu 20 aar efter forrentede han en del af denne sum hos godtfolk. Endvidere fortæller han i 1649, s... har jeg af min gode vilje udgivet til min antecessors kvinde nu saa nær 200 tønder haardt, rent korn og 200 skæpper, som jeg forrenter en stor del af endnu hos godtfolk og endogsaa har købt bygget hvert aar til hende, undtagen et aar, saa ogsaa en del af rugen, og stikker deraf i stor vidtløftighed her og der, saavelsom ogsaa førend at jeg fik' præstegaarden besat med heste og øg, kreatur og fæmon sat mig $i$ en meget stor gæld, som straks samme aar derefter af skab og skurer og lungesot døde mig fra.... og den skade, jeg i dette aar har lidt, 23 nød mig fradøde og over 60 faar.... Aar efter anden havde vandfloden tilføjet ham skade. Og da. svenskerne under Torstenson fejden plyndrende havde hjemsøgt egnen, kostede det ham nogle 1000 mark. ${ }^{170}$ )

187) Nye kirkehistoriske Samlinger VI 537; Kancelliets Brevbøger 1630 23/4, 23/6; Fra Ribe Amt VII 67; Sønderjydsk Maanedsskrift. 1936. 106.

168) Landemodeprotokollen $85 \mathrm{f}$.

$\left.{ }^{109}\right)$ Ribe Bispearkiv: Indkomne Breve 1569-1685 (V.); Hviding

Herred: Ad Reg. Nr. 7, Capsa 16, Pk. 6; Kragelunds Kopibog 137 f., 151.
170) Hviding Herreds Provstearkiv: "Prouste Bog udi Huidding Herret《 1649 . 
Der var ikke paa denne tid noget, som hed pension. Og da præsterne som regel ikke var særligt velhavende og ikke raadede over større frie kapitaler, som de kunde leve af i deres alderdom, blev de næsten altid $i$ deres embede, indtil døden for evigt gjorde dem tavs. Men naar alderen meldte sig, kneb det tit med at overkomme arbejdet. Der var derfor mange, som maatte holde kapellaner. Tit blev det ordnet saaledes, at disse blev udset til præstens efterfølger. I 1670 bevilgede kongen saaledes, at Niels Nielsen Aastrup maatte være sognepræst i Roager, naar den daværende præst Søren Jensen Skive godvilligt vilde afstaa kaldet til ham. Søren Jensen havde selv tilbudt den unge mand, der da var hører i Ribe. ".... at han sit kald med sin datter for mig vilde oplade og afstaa, dersom Eders Kongelige Majestæt allernaadigst det vilde bevilge .... I flere aar betjente Niels Aastrup kaldet, men den gamle præst vilde gerne beholde indtægterne for sig selv, selvom han kun prædikede nogle enkelte gange. Kapellanen klagede, og kongen og biskoppen formanede stærkt Hr. Søren, som iøvrigt ikke engang vilde give møde for biskoppen. ${ }^{171}$ ) Forholdet mellem de to er dog senere sikkert blevet lidt mere fredeligt. Thi aaret efter, i 1674, ægtede Niels Aastrup den gamle præsts datter.

Ogsaa Søren Hegelund i Skærbæk havde faaet en medhjælper, Henning Arendsøn (Fischer), som blev adjungeret ham med løfte om at blive hans efterfølger. Han udstedte en forpligtelse paa at betale præstegaarden, som havde kostet $\mathrm{Hr}$. Søren nogle 1000 mark lybsk. Men da det kom til stykket, vilde han ikke betale, trods det han sad inde med præstegaarden og havde pengene rede. Søren Hegelund klagede til kongen. Selvom han ikke gerne vilde trættes med medhjælperen, der var han egen dattermand, maatte han dog af hensyn til sine uopdragne børn bede om, at der blev givet svigersønnen tilhold om at betale ham hans tilgodehavende. Dette skete ogsaa. ${ }^{172}$ )

\footnotetext{
Pk. 1. Pk. 6.

172) Ribe Bispearkiv: Hviding Herred: Ad Reg. Nr. 7, Capsa 16,
}

171) Ribe Bispearkiv: Hviding Herred: Ad Reg. Nr. 7, Capsa 16, 
Som i disse to tilfælde var det meget ofte saaledes, at præstens datter fulgte med i købet. Selvfølgelig var det nærliggende, at de to unge kunde fatte tilbøjelighed for hinanden, men tit har det nok mere været praktiske hensyn, der spillede ind. Var der lidt god vilje hos begge parter, var det heller ingen daarlig maade at bringe det vanskelige spørgsmaal om aftægt til den gamle præst eller til enken ud af verden pa.a.

En anden meget almindelig udvej var det at faa sønnen til faderens efterfølger eller medhjælper. Da Jens Claudius i Daler var død omkring 1660, anmodede hans enke Lucia lensmanden i Ribe grev Schack om at sørge for, at hendes ældste søn Johannes Daler blev faderens efterfølger. Paa menighedens vegne stillede tolv mænd den samme anmodning. Enken sad med ni børn, hendes vilkaar var vanskelige. Sønnen var baade ude og hjemme, men særdeles i Ribe skole, flittigt blev holdt til bogen og havde gode gaver dertil. Del bad om, at der maatte holdes kapellan, indtil sønnen fik tilbørlig attestats fra universitetet i København. ${ }^{13}$ ) Johannes Daler blev dog aldrig præst i sit fødesogn, men i Braderup.

Men var der ingen søn eller svigersøn, der kunde blive kapellan eller tiltræde det ledige embede, maatte man tage en fremmed. I saadanne tilfælde blev det vanskelige spørgsmaal om aftægt til præsteenken ofte løst ved, at den nye præst ægtede forgængerens enke. Da præsten i Højer var død 1592, fik hans enke efter ansøgning hertugens brev paa, at hvis en lærd og kvalificeret mand vilde ægte hende, skulde han have embedet. En betingelse var det dog, at sognemændene ogsaa var tilfreds med ham. Den paagældende præstekone var en forertagsom dame, og da hun i 1637 atter blev enke, fik hun et nyt hertugeligt brev, der dels sikrede hende naadsensaarets. indtægt af kaldet, dels lovede, at hvis der kunde findes en kvalificeret person, der vilde ægte hendes barnebarn, skulde han havde fortrinsret til kaldet, dog under forudsætning af at

173) Schackenborg Godsarkiv: Breve, Resolutioner, Resolutioner m. m. samt Koncepter (1641) ca. $1660-1675$. 
menigheden ikke havde noget at indvende imod ham. ${ }^{174}$ ) I 1652 var Niels Christensen Friis blevet præst i Hygum. Han havde da forpligtet sig til at ægte forgængeren Peder Bertelsens enke Abel. Forpligtelsen var underskrevet af Niels Friis og hans fader. Imidlertid maa han senere være kommet paa andre tanker. Han nægtede at efterkomme sit løfte og blev truet med al landsens ulykker. Biskoppen og amtmanden fik ordre til at domme i sagen, og 1655 skrev biskoppen til provsten, at denne sammen med en anden præst skulde gøre det klart for Niels Friis, at hvis han ikke holdt sit løfte, skulde kirketjenesten og prædikestolen formenes ham. Suspensionen hang over hans hovede. Da Abel ogsaa havde været gift med Peder Bertelsens forgænger Jørgen Clausen Stuhr, der døde allerede i 1630, maa hun jo have været en del til aars. Man forstaar godt den unge mands betænkeligheder. Ogsaa i Ribe maa man trods alle trusler have haft forstaaelse derfor, thi striden endte med, at præsten skulde ansøge kongen om at slippe fra sit løfte. Hvis han fortsat skulde betjene embedet, maatte han skaffe kongelig resolution derpaa. Iøvrigt hedder det: »... Hvis den sag om naadsens aar og andre forretninger sig belanger, han af enken beskyldes for, det kan paa sine tilbørlige steder ved lov og ret udføres.... ${ }^{17{ }^{175}}$ )

\section{Degne og skoleforholdene:}

Degnenes stilling var paa mange maader en lignende som præstens. Ogsaa deres indtægter bestod $i$ det store og hele af naturalafgifter og enkelte accidenser. Degneboligerne var meget ringe, kun lige det aller nødtørftigste. Mange steder -- for eksempel i Lintrup-Hjerting -- var der ingen bolig til degnen. Dette hang dog antagelig sammen med løbedegnesystemet, og

174) Rolfs: anf. sted 85 f., 88.

${ }^{175)}$ Kragelunds Kopibog $39 \mathrm{f}$; Landemodeprotokollen $118 \mathrm{ff}$; Arends: Gejstligheden i Slesvig og Holsten I 47. 
reglen var, at der af menigheden var bygget et degnehus, ofte paa en syv fag, hvoraf de tre benyttedes til skole. ${ }^{176}$ )

I de nordlige sogne i Tørninglen blev degneembederne allerede før reformationen betjent af løbedegne fra. Ribe skole: I Haderslev artiklerne fra 1528 bestemmes det, at i de sogne, som ikke laa over en mils vej fra Ribe eller Haderslev, skulde sognene tage deres degne fra disse byers skoler, og i kirkeordi-. nansen fra 1539 findes en tilsvarende bestemmelse om, at sognene i nærheden af købstæderne skulde tage deres degne fra byernes skoler. ${ }^{177}$ )

Løbedegnene i Haderslev provsti forsvandt allerede i 1651, mens de i Tørninglen og det øvrige Danmark fortsatte deres tilværelse meget længere ned i tiden. ${ }^{178}$ ) I Farup var førstelektiehøreren i Ribe skole løbedegn, i Vester-Vedsted andenlektiehøreren og i Hviding tredielektiehøreren, mens disciplene tog sig af Højrup, Hjortlund, Kalvslund, Brøns, Toftlund, Øster-Lindet, Fole, Lintrup, Rødding, Hygum, Spandet, Roager, Rejsby og Vodder. Ret ofte holdt løbedegnene en stedfortræder eller substitut til at betjene degnetjenesten, og denne fik saa en vis del af indtægten. I Brøns var der 1649 en substitut, som varetog tjenesten, naar degnen fra Ribe ikke selv kunde komme til sognet $" . .$. for vandløb og uvejr, besynderlig om vintertid .... Han fik 12 skæpper byg. I 1709 fik substitutten i Hviding 10 mark dansk om aaret. Iøvrigt har denne ordning med løbedegne næppe været til fordel for menighederne. Thi det var-langtfra hver søndag, at degnene gav møde i kirken. I 1656 udtalte førstelektiehøreren i Ribe, at han i fem søndage ikke havde besøgt sit sogn. ${ }^{179}$ )

$\left.{ }^{176}\right)$ Ribe Bispearkiv: Indkomne Breve 1569-1685 (V.); Herredsbog for Møgeltønder, Daler og Emmerlev 1690; Haderslev Amtsarkiv: Forarbejder til Jordebogen 1706 ff.

177) Kinch: Ribe Bys Historie I 443; Sønderjydske Aarbøger 1889. 230; H. F. Rørdam: Danske Kirkelove I 101.

${ }^{178)}$ Schriften des Vereins für Schleswig-Holst. Kirchengeschichte 2. r. VII $428 \mathrm{ff}$.

179) Kinch: anf. sted I 443, II 731 f., 734 f., 737 f.; Hviding Herreds Provstearkiv: "Prouste Bog udi Huidding Herret» 1649; Haderslev Amtsarkiv: Forarbejder til Jordebogen 1706 ff. 
I Ribe stift var det vistnok i det store og hele sognemændene, der bestemte, hvem der skulde være degn for menigheden, dog saaledes at amtmændene skulde bekræfte valget. I de sogne, hvor der var privat patronatsret til kirkerne, var det patronen, der udnævnte, selv om sognets folk ogsaa i disse tilfælde synes at have haft indflydelse paa valget. I 1689 erklærede Mjolden sogns to kirkeværger, at degnesønnen Hans Nissen fra Brede to gange havde ladet sig høre i Mjolden kirke og havde behaget præst saavel som menighed, der paa præstens spørgsmaal erklærede sig tilfreds med ham. Han var ikke blot god til kirketjenesten, ".... men endog erfares om sin flittige informering ved ungdommen, som os her saavel som andre steder højt er angelegen.... ${ }^{180}$ )

I Slesvig stift var det præsten og sognemændene, der bestemte, hvem der skulde være degn, mens provsten konfirmerede valget. I Højst voldte degnene i det 16. og 17. aarhunarrede menighed og øvrighed mange kvaler. Da kapellanen Claus Jensen (Schmidt) ${ }^{181}$ ) var død i 1564, skulde der ansættes en degn i hans sted.. Herskabet paa Solvig havde som kandidat dets gartner Jens Worm, sognefolkene ønskede Hr. Claus' yngste søn Jacob som havde en stærkere stemme end den ældste søn Jens, der var præstens kandidat. Provsten holdt med menigheden, og Jacob Clausen blev degn i Højst. Hans søn Lorens Jacobsen blev senere hans efterfølger, men menigheden blev efterhaanden ked af ham, idet han havde mere lyst til landbrug end til at undervise børnene i katekismus, læsning, skrivning og regning. I 1643 blev han derfor afsat af provsten Bernhard Mouritius, og det blev ".... dem Hrr. Pastorn mit thodoen der geschwarnen und öldesten des Kirchspiels einen andern düchtigen köster, de dat gemeene beste und der Kinder

180) Trøjborg Godsarkiv: Pk. 8. Kirker og Skoler.

181) Om denne mand og hans slægt se Ludwig Andresen: Geschichte der Stadt Tondern 275 ff. 
wolfahrt trülicher, wo bethero geschehen, befödern, anthonehmen, heimgestellet und anbefahlen.... . $^{182}$ )

Inden degnene tiltraadte deres embede, skulde de i Ribe stift overhøres af biskoppen i Luthers katekismus og "vores kirkesangs øvelse ${ }^{183}$ ) $\mathrm{Hr}$. Jens Mikkelsen, sognepræst til Døstrup, havde undladt at sørge herfor og stod af denne grund i 1657 anklaget for landemodet. Han fremlagde herren til Trøjhorg, Daniel Rantzaus, kaldsbrev, som var ejendommeligt derved, at det lillod den unge degn Jens Iversen, at han for sin ungdoms skyld maatte gaa i skole et aar endnu, saa at han desto bedre kunde forestaa sit embede., Dette kaldsbrev fritog selvfølgelig ikke degnen for at stille til overhøring hos biskoppen, og Hr. Jens fik strenge paamindelser med hjem om forelobig at forbyde degnen degnestolen og degnetjenesten. Kort tid efter fik han dog paa grund af de vanskelige tider lov til at beklæde embedet, indtil han kunde blive eksamineret og faa sit kaldsbrev bekræftet. ${ }^{184}$ )

Foruden de kirkelige forretninger var degnen ogsaa forpligtet til «.... ungdommen at undervise i skolen med læsen og skriven saa og udi synderlighed udi deres katekismus og børnelærdom $\ldots . .{ }^{185}$ )

Ligesom tilfældet var mange andre steder i Slesvig skulde kapellanen i Skærbæk, der varetog degnetjenesten, ogsaa holde skole, hvad der flere gange gav anledning til strid. I 1637 fik kapellanen Hr. Jacob paamindelse om, »... at han skal holde skole og oplære børmene i deres katekismus efter hans ordinats og kaldsbrevs lydelse, eller derfor at stande til rette $\ldots .4\left({ }^{186}\right)$ Heller ikke den næiste kapellan Thomas Buck varetog sin skolegerning med den ildhu, som dette arbejde fordrer. Han havde forpligtet sig til $" . .$. en ustraffelig skole at holde, læesen, skri-

182) Højst Præstearkiv: B. d. 1. 1589-1900. Forskellige Breve og Dokumenter; Tønder Provstearkiv: Højst: "Küsterstelle«.

${ }_{183}$ ) Ribe Bispearkiv: Archidiakonatets Dokumenter vedr. Tørninglen $1576-1778$.

184) Landemodeprotokollen 147; Kragelunds Kopibog 90, 112.

185) Jyske Samlinger VII $144 \mathrm{f}$.

$\left.{ }^{186}\right)$ Landemodeprotokollen $14 \mathrm{f}$. 
ven og regnen anlangendes, og ellers derhos om ugen byerne $i$ sognet at besøge og ungdommen saavel som og tjenestetyende, fattig og rige, ingen forbigangendes, udi godtfolks hus at samle og den udi børnelærdom kristeligen at undervise .... «. ${ }^{187}$ ) Han holdt dog slet ikke selv skole, men havde ligefrem forpagtet den bort. Der klagedes over, at den blev forsømt, og selvom han mente, at hans stedfortræder varetog undervisningen paa forsvarlig maade, blev det dog indskærpet ham, at han skulde holde skole og undervise ungdommmen, ligesom det paalagdes ham, "... at naar degnen af skolen ikke gør officium, at han da betimeligen lader domini episcopi (Hr. biskoppen) og rectori scholæ det betimeligen forstændige, paa det derefter ikke skal ellers følge inconvenienser enten udi en eller anden maade $\ldots . \ll^{188}$ ) Det var iøvrigt samme Thomas Buck, der optraadte saa lidet passende i Skærbæk kirke. Egentlig egnet som ungdommens vejleder og opdrager kan han næppe siges at have været. Iøvrigt var sognefolkene i Skærbæk slet ikke tilfreds med denne ordning af skolevæsenet, idet de onskede tilladelse til at holde en særlig skolemester i Vester-Gasse, Barsbøl og Mosbøl. De hævdede, at sognet var for stort, og at de paagældende byer laa for langt borte fra kirken, hvor skolen holdtes. Denne var ogsaa for lille. Hvis alle sognets børn kom til kirkeskolen, kunde de hverken faa plads til at sidde eller staa. Kapellanen Jacob Olufsen satte sig imod denne nyordning, da den vilde betyde en nedgang $i$ indtægter for ham. ${ }^{189}$ )

I Danmark blev den tvungne skole- eller undervisningspligt først indført ved Danske Lov. I hertugdømmet var det dog allerede tidligere fastslaaet, at børnene skulde gaa i skole. En betydningsfuld indsats $i$ denne retning havde den kongelige superinten'dent Stephan Clotz gjort. I Flensborg amt fastslog en skolekonstitution, som han og amtmanden Cai Ahlefeldt havde udstedt allerede i 1643 , at beboerne alle steder skulde være for-

$\left.{ }^{187}\right)$ Ribe Bispearkiv: Hviding Herred: Ad Reg. Nr. 7, Capsa 16,

$\left.{ }^{188}\right)$ Landemodeprotokollen $64 \mathrm{f}$.

189) Ribe Bispearkiv: Indkomne Breve 1569-1685 (V.). 
pligtet til, sommer saavel som vinter, at sende deres børn i skole. Hvis de ikke opfyldte dette krav, blev de truet med straf. I de følgende aar arbejdede Stephan Clotz videre med spørgsmaalet. I 1646 udstedtes en almindelig kongelig forordning, der selvfølgelig kun havde gyldighed for de kongelige dele af hertugdømmet og kun for de dele deraf, som tilhørte Slesvig stift. Det bestemtes heri, at der skulde tillægges skolelærerne en vis, omend ringe indtægt«, "... damit die Leute gleichsam gezwungen werden ihre Kinder in die Schulen .... abzufertigen und zu schicken .... ${ }^{100}$ ) Den 20. august $1650 \mathrm{og} 11$. januar $1651 \mathrm{ud}-$ stedtes der nye, mere vidtgaaende forordninger, henholdsvis vedrørende skolerne i Haderslev og Flensborg amter. I disse blev skolepligten fastslaaet for skolerne paa landet. De, der ikke vilde sende deres børn i skole, skulde præsten true. Og hvis det ikke hjalp, skulde der ske anmeldelse til den verdslige myndighed. I Haderslev amt skulde der i hvert sogn kun være een skolemester, mens vinkelskolerne skulde afskaffes. Kun i de byer, der laa mere end en fjerdingvej fra sogneskolen, var det tilladt at have en særlig skolemester. ${ }^{191}$ )

I de dele af Vestslesvig, der hørte under Gottorp og Slesvig stift, synes der at være indført tvungen skolepligt endnu tidligere end i de kongelige omraader, som hørte til Slesvig stift. Selve forordningen herom synes ikke at være bevaret, men kendes dog af omtale. I et brev fra 31. marts 1648 skriver præsten i Abild, Matthias Friis, til amtsskriveren i Tønder: ".. Weile aber, wie der Herr aus des Hern præposito mir desfals ertheilten testimonio sich wirt zu erinnern wissen, im Namen Ihrer Hochfürstelichen Durchlautigkeit von seligen Hern Superintendenten hin und wieder im Tunderischen Ampte Anord-

190) Rendtorff: Die schlesw.-holst. Schuloranungen (Schriften des Vereins für. schlesw.-holst. Kirchengeschichte 1. r. II) 239 f. $0 \mathrm{~g} 41$ ff.

$\left.{ }^{101}\right)$ Afskrift i Bov sogns ældste kirkebog 60 ff.; Top. Haderslev Amt: (1434-1748) "Copiale von Priv. und Verordnungen p. p. ...." $201 \mathrm{f}$; Rhode: Samlinger til Haderslev Amts Beskrivelse $131 \mathrm{f}$.; Th. 0. Achelis: Deutsche und Dänische Schulen einer Schleswiger Grenzstadt im Wandel der Jahrhunderte 11 f.; junf. Stephan Clotz' udkast fra 1651 (Rendtorff 43 ff.). 
nung gemacht worden, daz ein jedweder seine Kinder, so des Alters, zur Schuelen zu halten und in Entstehung dessen gleichvoll dem Schuelmeister sein Gebür zu geben sollte schuldig sein .... ${ }^{192}$ ) Forordningen maa antagelig være udstedt af Jacob Fabricius, der var generalsuperintendent fra 1640 til 1645, eller muligvis af hans fader af samme navn, og den tanke er nærliggende, at det er disse bestemmelser, som Stephan Clotz har efterlignet.

Den nævnte Matthias Friis laa i evig kiv og strid med sine sognebørn. Han havde energi, vilde reformere og ruske op. Men hans sognebørn vilde blive ved det tilvante og først og fremmest undgaa alle reformer, der kunde komme til at betyde forøgede udgifter for dem. Dette kom tydeligt frem i den strid, han havde med dem angaaende skolevæsenet, som han nærede en stærk interesse for. Da han tiltraadte sit embede, var der liverken skolehus eller skolemester. Det lykkedes ham at faa bygget et lille degnehus og faa en dygtig mand til degn. Men beboerne nærede uvilje mod denne og vilde ikke sende deres børn i skolen. De vilde heller ikke betale degnen, men mente, at præsten skulde gøre det. Nogle af beboerne holdt en privat sommerskole. Men han fandt det naturligt, at degnen besørgede undervisningen af alle børnene, og at udgifterne hertil blev paalignet hele sognet. Og iøvrigt udtrykte han i et brev til hertugen ønsket om, at sognefolkene fik paalagt at holde deres børn til skole .... von siebenden Jahren an .... bis so lange sie ihren Catechismus sampt den Fragstücken der Beicht zur Genüge gefasset (und) dem Schulmeister Winter und Sommer.... wachentlich Schulgebühr zu entrichten .... .

Omsider lykkedes det at faa en ordning med sognebørnene. I en kontrakt, som blev indgaaet den 10. juni 1648 og konfirmeredes den 15. juni samme aar, lovede de flittigt at holde deres børn $i$ skole og ikke sende dem i skriftestolen, før de var overhørt af præsten og fundet dygtig dertil. Endvidere forplig-

${ }^{102)}$ Acta A. XX. 2531 (Ra.). For Aabenraa amts vedkommende se: Zeitschrift der Gesellschaft für Schlesw.-Holst. Geschichte LXV 220. 
tede de sig til at holde bornene borte fra vinkelskoler, dog med undtagelse af dem, der boede i de fjerntliggende byer; for deres vedkommende skulde der træffes overenskomst med degnen om en erstatning. Aaret efter indgik man indenfor sognet en forening om en vis aarlig udgift til en sommerskole. Tre aar senere blev denne overenskomst bekræftet af amtmanden. ${ }^{193}$ )

Som man ser, var skoleundervisningens formaal ikke saa meget at uddanne og forberede børnene til det praktiske liv, inen først og fremmest at gøre dem skikket til at deltage i menighedens religiøse liv. De fleste steder blev der dog i det 17. aarhundrede skabt et grundlag, hvorpaa der senere kunde bygges videre.

Joh an Hvidtfeldt.

193) Acta A. XX. 2531 (Ra.); Acta C. V. 147. 